\title{
Preliminary Assessment of Risk from Toxic Materials that Might Be Mobilized in the Decommissioning of Aberdeen Proving Ground Building E5032
}

by D.H. Rosenblatt* and K.L. Brubaker

Reclamation Engineering and Geosciences Section, Energy Systems Division, Argonne National Laboratory, 9700 South Cass Avenue, Argonne, Illinois 60439

December 1991

Work sponsored by United States Army, Aberdeen Proving Ground, Maryland

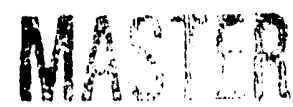

"Rosenblatt is affiliated with Argonne's Environmental Assessment and Information Sciences Division. 


\section{Contents}

Abstract...................................................................... 1

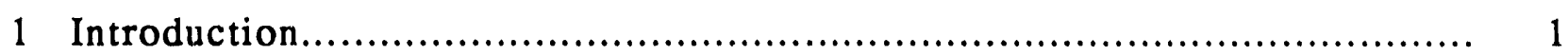

2 Predemolition Activities.......................................................... 3

3 Possible Building E5032 Contaminants ....................................... 4

3.1 Potential Contaminants Associated with Building E5032 Activities ................ 4

3.2 Properties of the Suspected Contaminants of Concern ........................... 4

3.2.1 White Phosphorus ..................................................... 4

3.2 .2 Mustard........................................................... 5

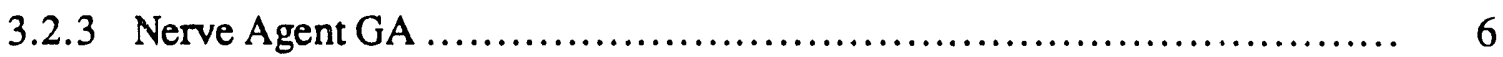

3.2.4 Incendiaries Triethylaluminum and Thermite ............................. 7

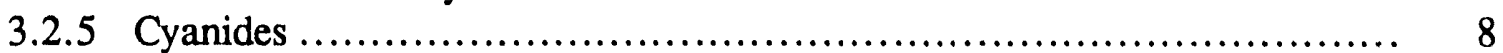

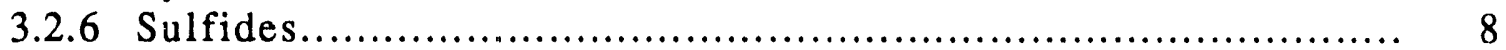

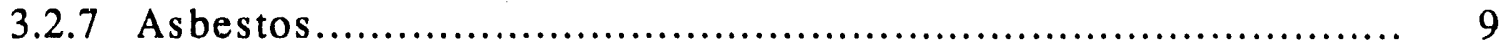

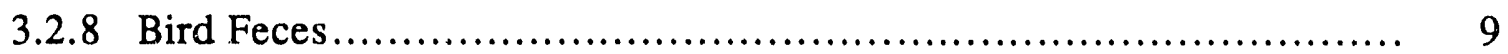

3.2 .9 Lead............................................................. 9

3.3 Probability of Encountering Substances of Concern during Demolition ............ 10

3.4 Development of Reference Doses for Potential Contaminants for Use in

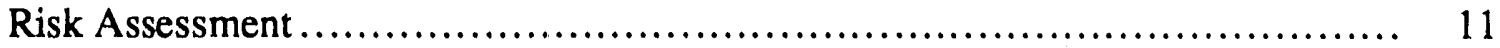

4 Decommissioning Concepts ................................................ 13

4.1 Decommissioning Concepts that Had Been Considered for Building E5625 ........ 13

4.2 Decommissioning Concepts for Building E5032.................................. 14

5 Occupational Risk Assessment.............................................. 16

5.1 Inhalation of Respirable Dust and, Where Applicable, Vapor ................... 16

5.1 .1 Scenario I ........................................................... 16

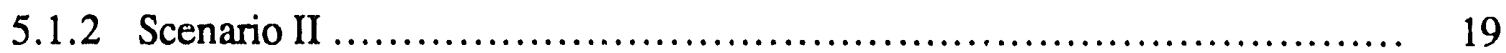

5.2 Ingestion of Particulates ...................................................... 22

5.2.1 Assumptions Regarding Ingestion of Soil and Dust ...................... 22

5.2.2 Conclusions as to Toxicant Exposure by Ingestion....................... 22

5.2.3 Permissible Toxicant Levels in the Concrete Floors ........................ 22

5.3 Dermal Exposure ....................................................... 23

5.3.1 Assumptions Regarding Contact of Skin with Soil and Dust............... 23

5.3.2 Conclusions as to Toxicant Exposure .................................. 23

5.3.3 Permissible Toxicant Levels in the Concrete Floors ...................... 23 


\section{Contents (Cont'd)}

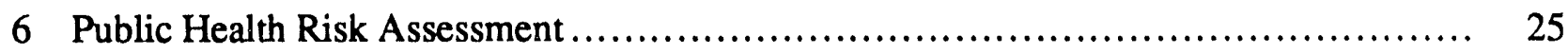

6.1 Inhalation of Respirable Dust and, Where Applicable, Vapor ................... 25

6.1.1 Assumptions Regarding Inhalation of Suspended Particles.................. 25

6.1.2 Permissible Toxicant Levels in the Concrete Floors ..................... 25

6.1.3 A Special Concern Regarding Cyanide and Sulfide.......................... 26

6.2 Ingestion of Particulates................................................... 26

6.2.1 Assumptions Regarding Ingestion of Concrete Particles................... 26

6.2.2 Conclusions as to Toxicant Exposure by Ingestion...................... 27

6.2.3 Permissible Toxicant Levels in the Concrete Floors ....................... 27

6.3 Dermal Exposure......................................................... 27

6.3.1 Assumptions Regarding Contact of Skin with Soil Containing

Concrete Dust................................................... 27

6.3.2 Conclusions as to Toxicant Exposure ................................. 28

6.3.3 Permissible Toxicant Levels in the Concrete Floors ....................... 28

6.4 Risks to Public Health and the Environment from Ranwater Runoff .............. 28

6.4.1 Reasonable Assumptions as to Transport of Toxicants by Runoff............ 28

6.4.2 Toxicant Exposure from Rainwater Runoff............................... 29

6.4.3 Permissible Toxicant Levels in the Concrete Floors ...................... 29

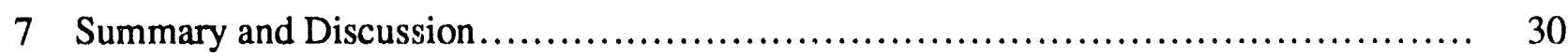

References................................................................. 33

\section{Tables}

1 Occupational Reference Doses for Potential Contaminants ......................... 12

2 Concrete Floor Occupational Health Criteria, Scenario I................................... 31

3 Concrete Floor Occupational Health Criteria, Scenario II ................................ 31

4 Concrete Floor Public Health Criteria, Scenario II ............................. 32

5 Concrete Floor Occupational Health Criteria for Maximum Allowable Dust Level, Scenario I 


\title{
Preliminary Assessment of Risk from Toxic Materials that Might Be Mobilized in the Decommissioning of Aberdeen Proving Ground Building E5032
}

by

\author{
D.H. Rosenblatt and K.L. Brubaker
}

\begin{abstract}
Aberdeen Proving Ground Building E5032 is scheduled for decommissioning, that is, for demolition. Because the building was formerly used for small-scale operations with incendiary and toxic chemical agents, it presents unusual concerns for occupational and public health safety during the demolition. For this reason, an anticipatory risk assessment was conducted, taking into consideration the building's history, properties of potential residuai contaminants (particularly chemical and incendiary agents), and assumptions relating to meteorological conditions and envisioned modes of demolition. Safe maximum levels in concrete floors for the worst case were estimated to be: white phosphorus, $3,200 \mathrm{mg} / \mathrm{kg}$; mustard, $94 \mathrm{mg} / \mathrm{kg}$; nerve agent GA (tabun), $6 \mathrm{mg} / \mathrm{kg}$; cyanide, $500 \mathrm{mg} / \mathrm{kg}$; and sulfide, $1,400 \mathrm{mg} / \mathrm{kg}$. These values will serve as planning guidance for the activities to follow. It is emphasized that the estimates must be reviewed, and perhaps revised, after sampling and analysis are completed, the demolition methodology is chosen, and dust emissions are measured under operating conditions.
\end{abstract}

\section{Introduction}

Aberdeen Proving Ground (APG), in the state of Maryland, is currently managing a comprehensive Installation Restoration Program involving more than 360 solid waste management units contained within 13 study areas under an Interagency Agreement with the U.S. Environmental Protection Agency (EPA). One such area involves the West Branch of Canal Creek, which will require a Source Definition Study because of the ongoing release of volatile organic compounds (VOCs) into the creek. Thirteen buildings in this area have been identified as potentially contaminated, including Building E5032, and are a potential source of VOCs (Borland et al. 1989). The buildings have been abandoned, and a variety of process equipment, sumps, drains, ventilation systems, and underground storage tanks remain. These items may contain liquid, solid, or vapor contamination of unknown nature.

APG plans to decommission the buildings, thereby eliminating the potential for release of contaminants into the environment. Argonne National Laboratory has been asked to develop a plan 
and scope of work for decommissioning these buildings, the first of which will be Building E5032 (earlier designated Building 99).

This document concerns estimation of levels of toxic matcrials below which there would be no health risks to samplers, demolition workers, government employees in the vicinity, or the somewhat further removed general population during the decommissioning of Building E5032. These levels are evaluated in the context of a risk management strategy and of possible decommissioning scenarios. In particular, risks from toxic chemicals, should they exist, are considered in terms of the mobilization of toxic residues initiated by cleanup and demolition activities and are dependent on how these activities are executed. It must be emphasized that the actual demolition procedures to be used have not yet been determined; thus, the evaluations performed below are based only on reasonable assumptions as to how the demolition will be carried out.

In its current form, this report is not a risk assessment document as construed by the EPA (EPA 1989b); rather, it anticipates data collection and evaluation. To the extent possible, conduct of the latter activities will be shaped by questions raised by the present examination and will serve to correct some of the assumptions made here. In view of the present complete lack of information on the existence, distribution, or quantities (if any) of toxic chemicals in Building E5032, the emphasis is on estimating safe levels in the material most likely to have been in contact with -- and most able to absorb -- toxic substances, namely concrete.

In consideration of the above statements, the present document is to be treated as preliminary. Eventually it will be integrated with results of the sampling program and will be updated to incorporate consideration of conditions arising from the demolition procedures that will actually be employed.

Information about Building E5032 -- especially regarding chemicals present there in the past -- was taken from a recent historical records search (Borland et al. 1989).

It is assumed that no respiratory protection will be used (unless nuisance dust norms are exceeded) during the demolition of Building E5032. Workers can protect most of their bodies with ordinary clothing without finding such protection too cumbersome, whereas respiratory protection tends to impair work efficiency and imposes considerable added heat load. 


\section{Predemolition Activities} activities:

It is expected that the following tasks will be carried out before beginning actual demolition

1. A review of existing documentation that describes or is relevant to the history of activities associated with Building E5032. This documentation should include, but not be limited to:

a. Reports from previous investigations or descriptions of building activities (e.g., Borland et al. 1989).

b. The Edgewood Area facility assessment report (Nemeth 1989).

c. Existing plans and drawings, current and archival.

d. Reports from previous geological, geophysical, environmental, and other such studies conducted entirely or partially in the vicinity of the building.

2. A geophysical survey in the immediate vicinity of the building to identify nearby underground structures assoriated with past building activities. Survey techniques should include the following:
a. Ground-penetrating radar.
j. Magnetometer measuremients.
c. Resistivity measurements.

3. A detailed physical examination of the building to identify and accurately locate areas where toxic residues were likely to persist, such as sumps, drains, porous materials, any remaining process equipment, or areas of high spill probability.

4. A comprehensive sampling and analysis program to identify any toxic substances present and to determine their concentrations in various compartments. In this document, "compartment" will refer to any place, generic or specific, where toxic substances might be found. The sampling and analysis phase may need to be conducted in several stages, depending on initial and subsequent findings.

5. Preparation of predemolition documentation, including a final risk assessment report and a demolition plan, as well as other plans and documentation required for compliance with regulatory and institutional requirements. Necessary reviews and permits will have to be obtained. 


\section{Possible Building E5032 Contaminants}

\subsection{Potential Contaminants Associated with Building E5032 Activities}

Built in 1918, Building E5032 was first used as an incendiary drop bomb filling facility. In 1922, it was employed as a laboratory-scale explosives manufacturing complex. Over the years, the building has been utilized for various pilot plant operations. Substances handled there include toxic agents $\mathrm{H}$ (technical grade mustard) and/or HD (distilled mustard), GA (tabun, a nerve agent), incendiaries WP (white phosphorus) and TEA (triethylaluminum), and a variety of flammable liquids, typically oils and other petroleum distillates.

The substances associated with Building E5032 that are listed below were taken from the historical records search documentation of Borland et al. (1989). Lead was added as a suspected contaminant because lead paint was so commonly used on both interiors and exteriors of buildings until well into the second half of the present century; no attempt will be made at this time, however, to quantify potential risks (and occupational risks in particular) from lead because its distribution differs from that assumed for other substances of interest.

Substances of possible concern at Building E5032 are white phosphorus (WP), mustard "gas" (HD), nerve agent GA, triethylaluminum (TEA), thermite, cyanides, sulfides, asbestos, bird feces, and lead. Substances of essentially no concern are nitrates, polymethyl methacrylate, aluminum oxide, and phosphates.

Four of the suspected "contaminants" were designated as being of essentially no concern on the basis of the following considerations. Nitrates (which ordinarily designate only inorganic nitrates, or occasionally organic nitrate esters, but never nitroaromatics) are nonvolatile watersoluble inorganic salts that occasionally pollute water supplies or that -- in excess -- are undesirable plant nutrients in ponds or lakes. They are otherwise so innocuous as to permit their widespread use as fertilizers. Phosphates (presumably meaning inorganic phosphates, not organic phosphate esters) are likewise nonvolatile and are harmless enough to be used as fertilizer without special protectiojn; in ponds or lakes, they too are plant nutrients that are undesirable in excess. Polymethyl methacrylate is a polymer of no toxicity, volatility, or water solubility. Aluminum oxide, a common soil constituent, is essentially insoluble in water and nontoxic.

\subsection{Properties of the Suspected Contaminants of Concern}

\subsubsection{White Phosphorus}

The white, low-melting $\left(44^{\circ} \mathrm{C}\right)$ allotropic form of elemental phosphorus, $\mathrm{P}_{4}$, is pyrophoric, burning to phosphorus pentoxide, $\mathrm{P}_{4} \mathrm{O}_{10}$. However, under appropriate conditions, a passivating surface oxide layer retards oxidation so that WP-containing particulates may remain as WP, suspended in air, for a period of time (Davidson et al. 1987). White phosphorus can exist for years in anaerobic sediments or soils. In the laboratory it is normally kept under water to prevent 
combustion. WP has a solubility of $4.1 \mathrm{mg} / \mathrm{L}$ in water at $25^{\circ} \mathrm{C}$ and a vapor pressure of 0.023 torr at that temperature. From these data one calculates a dimensionless Henry's Law constant of 0.0039. Spanggord et al. (1985) investigated the dissolution of WP from soil with slowly flowing oxygen-saturated water. They estimated that a $1-\mathrm{cm}^{3}$ sphere of phosphorus dissolving at a rate of $0.0058 \mathrm{mg} / \mathrm{h}$ would lose $2.8 \%$ of its mass in one year; the persistence of this particle would be orders of magnitude longer than that of WP dissolved in soil water. Although dry WP dust could not survive for years in the cracks and crevices of a building, nor would more massive amounts persist in contact with air, WP could survive in deep moist or water-saturated soil or sediment (and in sealed vessels or pipes), especially if covered by water. Yet nearby soil samples might yield no trace of WP. Penetration of pockets of WP by tools during demolition or excavation operations would quickly cause its ignition. Being alert to this possibility and taking precautions to exclude flammable materials from the vicinity should serve to avoid injuries due to burning WP on the skin or to otherwise dangerous fires.

The volatilization half-life of dissolved WP from a 1-m-deep pond under moderately turbulent conditions was estimated at $5.6 \mathrm{~h}$ (Spanggord et al. 1985). The half-life for dissolved WP in overland runoff water, under the arbitrary assumption of a $1-\mathrm{cm}$ depth, should therefore be less than $3.4 \mathrm{~min}$ (since the half-life is inversely proportional to the depth).

WP in water is quite toxic to aquatic organisms, with chronic effects seen at as low as 0.4 parts per billion (ppb) (Davidson et al. 1987). Aside from the skin-necrotizing effects of burning WP (probably caused in part by the oxide combustion products, which react with water to form fairly strong acids), WP is also quite toxic systemically to humans. The minimum acute lethal oral dose may be as low as $50 \mathrm{mg}$. Chronic occupational exposure of humans has resulted mainly in necrosis of the jawbone. An acceptable daily intake for WP, protective of the most sensitive subpopulation of the general population, has been calculated as $0.0105 \mathrm{mg} / \mathrm{d}$ for a $70-\mathrm{kg}$ adult, which is equivalent to a reference dose of $0.00015 \mathrm{mg} / \mathrm{kg} \cdot \mathrm{d}$ (Davidson et al. 1987). The occupational Final Rule Limit for WP, a time-weighted air concentration exposure limit for an 8-h day, is $0.1 \mathrm{mg} / \mathrm{m}^{3}$ (DOL 1990).

Thus far in the present inquiry, documents describing techniques for the safe removal of WP from pipes or buried deposits have not been identified. It would seem, however, that controlled combustion would eliminate more massive amounts of the element. Final cleanup could be accomplished with mild caustic solutions containing a small amount of potassium permanganate. The caustic would neutralize the phosphorus oxides and acids, and the permanganate would oxidize any remaining WP.

\subsubsection{Mustard}

Mustard "gas" or bis(2-chloroethyl) sulfide can be made by reacting thiodiglycol (HO- $\mathrm{CH}_{2}-\mathrm{CH}_{2}-\mathrm{S}-\mathrm{CH}_{2}-\mathrm{CH}_{2}-\mathrm{OH}$ ), which is virtually nontoxic, with hydrogen chloride or by treating ethylene with sulfur monochloride $\left(\mathrm{S}_{2} \mathrm{Cl}_{2}\right)$ (Rosenblatt et al. 1975; Small 1983, 1984). The symbol for distilled mustard is $\mathrm{HD}$. $\mathrm{HD}$ is a dense liquid $\left(\mathrm{d}=1.27 \mathrm{~g} / \mathrm{cm}^{2}\right.$ at $\left.20^{\circ} \mathrm{C}\right)$ that freezes at $14.4^{\circ} \mathrm{C}$ and boils at $228^{\circ} \mathrm{C}$. It has a vapor pressure of 0.072 torr at $20^{\circ} \mathrm{C}$ and 0.11 torr at $25^{\circ} \mathrm{C}$. Its solubility in water. is quite low; for example, solubility is $0.075 \%$ at $10^{\circ} \mathrm{C}$ and $0.092 \%$ at $22^{\circ} \mathrm{C}$ 
(whence an estimated value of $0.097 \%$ at $25^{\circ} \mathrm{C}$ ), and the calculated rate of solution for $10^{\circ} \mathrm{C}$ is $6.77 \times 10^{-5} \mathrm{mg} / \mathrm{cm}^{2} \cdot \mathrm{s}$. Because of this very low rate of solution in water, HD is difficult to decontaminate (to thiodiglycol) by aqueous hydrolysis despite the relatively high first-order rate constant of the reaction once the $\mathrm{HD}$ is in solution. For example, the half-life of very dilute HD in distilled water is about $4.5 \mathrm{~min}$. From the solubility and vapor pressure of the compound at $25^{\circ} \mathrm{C}$, one calculates a dimensionless Henry's Law constant of 0.00097 . HD is most often decontaminated by oxidation with calcium hypochlorite (the heat of reaction is sometimes sufficient to cause the mixture to ignite) or by decomposition with the alkaline organic "DS-2" solution. Oxidation, for example by hypochlorite, proceeds through the less toxic sulfoxide and sulfone.

Bulk -- as opposed to dissolved, adsorbed, or well-dispersed -- HD (or H, a mure technical grade of mustard) can persist deep in the soil or under relatively quiescent water for years. This persistence is probably caused in part by the formation of oligomeric degradation products of limited hydrolysis that coat the surface of the HD mass. Samples of soil or groundwater taken very near such a mass might show no trace of the active agent. Films of HD on or near the soil surface would volatilize or hydrolyze rather quickly, that is, within about three weeks.

When pulverized concrete was added to a $104-\mathrm{mg} / \mathrm{L}$ hexane solution of $\mathrm{HD}$ at $25^{\circ} \mathrm{C}$, at a ratio of $0.36 \mathrm{mg}$ of $\mathrm{HD}$ per gram of concrete, the HD disappeared (following first-order kinetics) with a half-life of $40 \mathrm{~h}$, much more rapidly than without the concrete. Furthermore, when 0.25 -in.-thick coupons of concrete weighing $210 \mathrm{~g}$ were spiked at doses of 0.045 or $1.8 \mathrm{mg} \mathrm{HD}$ per gram of concrete ( 9.5 or $378.5 \mathrm{mg} \mathrm{HD}$, respectively), it was impossible to recover any HD in the head space above the coupons after a reaction time of $24 \mathrm{~h}$, even though the coupons were heated to $60^{\circ} \mathrm{C}$ to expel HD vapors (Carpenter and Hill 1988). The authors of that work cite an earlier study that indicated that loss of HD was $34 \%$ ccmplete in $1 \mathrm{~h}$ and $99 \%$ in $4 \mathrm{~h}$ when HD was spread on a concrete surface at a loading of $10 \mathrm{~g} / \mathrm{m}^{2}$. Such tests indicate that concrete is chemically reactive with $\mathrm{HD}$, which could not survive even for weeks in that medium.

$\mathrm{H}$ and $\mathrm{HD}$ may produce serious toxic symptoms after inhalation, dermal exposure (blistering as well as systemic effects), or oral ingestion. The human median lethal exposure by inhalation is about $1,500 \mathrm{mg}-\mathrm{min} / \mathrm{m}^{3}$ (i.e., $50 \mathrm{mg} / \mathrm{m}^{3}$ for $30 \mathrm{~min}$ ). Assuming $100 \%$ retention by the lungs and a breathing rate of $2 \mathrm{~m}^{3} / \mathrm{h}$, this exposure is calculated to give an $\mathrm{LD}_{50}$ of $0.7 \mathrm{mg} / \mathrm{kg}$. Exposure of the eyes to $200 \mathrm{mg}-\mathrm{min} / \mathrm{m}^{3}$ of $\mathrm{HD}$ causes severe to total impairment of vision. The compound is also a carcinogen, according to both animal experiments and somewhat equivocal epidemiological evidence. McNamara et al. (1975), as cited by Rosenblatt et al. (1. 15), recommended an air concentration limit of $0.003 \mathrm{mg} / \mathrm{m}^{3}$ per 8 -h workday for workers in cleanup operations and a limit of $0.0001 \mathrm{mg} / \mathrm{m}^{3}$ for the general population. In a report to the EPA, Ottinger et al. (1973), as cited by Rosenblatt et al. (1975), recommended a level of $3 \times 10^{-6} \mathrm{mg} / \mathrm{m}^{3}$ for the general population. Droplets of $\mathrm{HD}$ as small as $0.0025 \mathrm{mg}$ cause erythema.

\subsubsection{Nerve Agent GA}

GA (tabun) is one of the G-series nerve agents (G-agents). Such agents and related phosphorus-containing pesticides act by more or less irreversibly phosphonylating (or, as with 
GA, phosphorylating) the enzyme acetylcholinesterase, which is essential to the process of nerve impulse tansmission (Small 1983, 1984; Edgewood Arsenal 1974). The structure of GA is $\mathrm{C}_{2} \mathrm{H}_{5} \mathrm{O}-\mathrm{P}(=\mathrm{O})(\mathrm{CN}) \mathrm{N}\left(\mathrm{CH}_{3}\right)_{2}$.

$\mathrm{GA}$ is moderately volatile, with a vapor pressure at $25^{\circ} \mathrm{C}$ of 0.07 torr. It is also fairly water-soluble $\left(7 \%\right.$ at $20^{\circ} \mathrm{C}, 9.8 \%$ at $25^{\circ} \mathrm{C}$ ) and is rather easily hydrolyzed, with a half-life of $8.5 \mathrm{~h}$ at $\mathrm{pH} 7$ (;lightly less at $\mathrm{pH} 4-5$ ) and $20^{\circ} \mathrm{C}$; it hydrolyzes even more easily in alkaline solution. From the solubility in water and the vapor pressure at $25^{\circ} \mathrm{C}$, one calculates a dimensionless Henry's Law constant of $6.2 \times 10^{-6}$. GA persists only about $24-36 \mathrm{~h}$ in the soil. Unless G-agents have been kept in tightly sealed vessels, preferably with stabilizers, they are certain to degrade or volatilize over time. The hydrolysis of G-agents is catalyzed by hypochlorite ion. The hydrolysis products of G-agents are essentially nontoxic, except for the cyanide from GA. Cyanide is destroyed, however, by hypochlorite solutions.

Although the survival of GA in contact with concrete apparently has not been tested, that of the closely related GB has. When pulverized concrete was added to hexane solutions of GB at $25^{\circ} \mathrm{C}$, at ratios of 0.045 to $1.8 \mathrm{mg}$ of GB per gram of concrete, about $99 \%$ of the GB disappeared within 30 min, much more rapidly than without the concrete (Carpenter and Hill 1988). An earlier study citted by the authors of that work indicated that loss of GB applied to concrete at a loading of $.271 \mathrm{~g} / \mathrm{m}$ " was at least $70 \%$ in $2 \mathrm{~h}$; the study concluded with the opinion that decontamination of concrete surfaces exposed to GB would be unnecessary after $6 \mathrm{~h}$. It is evident that concrete reacts chemically with GB, which could not survive for hours in that medium, let alone for years.

The 10 -min median acute lethal inhalation toxicity of GA for dogs is $320 \mathrm{mg}-\mathrm{min} / \mathrm{m}^{3}$, and the median acute intraperitoneal dose to rats is approximately $0.8 \mathrm{mg} / \mathrm{kg}$. For man, the estimated median acute lethal inhalation toxicity over a period of 0.5 to $2 \mathrm{~min}$ is $135 \mathrm{mg}-\mathrm{min} / \mathrm{m}^{3}$ for a breathing rate of $15 \mathrm{~L} / \mathrm{min}$. The median moderately incapacitating dosage for man $\left(\mathrm{ICt}_{50}\right)$ has not been estimated for GA, but for GB, which is about twice as toxic by inhalation, the determined value for $10-\mathrm{min}$ exposures is $40 \mathrm{mg}-\mathrm{min} / \mathrm{m}^{3}$. An indefinite occupational control limit for $\mathrm{GB}$ (8-h day), with a maximum averaging period of $10 \mathrm{~d}$, was established as $0.0001 \mathrm{mg} / \mathrm{m}^{3}$. For the present study, this limit has been doubled to $0.0002 \mathrm{mg} / \mathrm{m}^{3}$ for the less toxic GA. For the general population, the indefinite-exposure value for both $\mathrm{GB}$ and $\mathrm{GA}$ is $0.000003 \mathrm{mg} / \mathrm{m}^{3}$, with a maximum averaging time of $72 \mathrm{~h}$, whish can run consecutively. A GA concentration of $0.0028 \mathrm{mg} / \mathrm{L}$ in drinking water has been recommended as the maximum permissible concentration for the public following an unplanned agent release (Baronian 1988).

There are numerous signs and symptoms of G-agent poisoning. Noteworthy among these are contraction of the pupils of the eye, runny nose, tightness of the chest, and increased salivation, sweating, and lacrimation.

\subsubsection{Incendiaries Triethylaluminum and Thermite}

The incendiary triethylaluminum or TEA is extremely pyrophoric when exposed to air and reacts violently with water to form aluminum hydroxide and ethane, both of which are normally nontoxic (Ethyl Corporation 1990, undated). Although encapsulation in a napalm matrix might 
suppress the pyrophoric properties of TEA, it is inconceivable that a napalm-TEA mixture could persist in the open over a period of years without complete degradation of the TEA. Thus, the only TEA concern in Building E5032 is that an old sealed (perhaps unlabeled) metal cylinder containing the pure inaterial migh: yet be there. If a suspect container is found, the Ethyl Corporation's technical staff may be called (504-388-7717; emergency 504-344-7147) for advice or assistance.

Thermite, a mixture of iron oxide and aluminum powders that reacts vigorously upon ignition to generate intense heat, has no toxicological significance (Kaye 1980). The chief concern would be that sufficient quantities might accidentally be ignited. Thus, it might be prudent to bring individuals accustomed to working with thermite to Building E5032 to look for indications of its presence and to provide advice as to its ignitability. Small amounts of thermite probably could not remain in the open for long periods ( 70 years in this case) withcut the aluminum being oxidized to the harmless oxide.

\subsubsection{Cyanides}

Cyanide salts are converted to the gas hydrogen cyanide (HCN or agent AC) on acidification. The boiling point of $\mathrm{HCN}$ is $25.7^{\circ} \mathrm{C}$. The $\mathrm{pK}_{\mathrm{a}}$ at $25^{\circ} \mathrm{C}$ is 9.21 , so that more than $99 \%$ of aqueous $\mathrm{HCN}$ is un issociated at $\mathrm{\mu H} 7$. The vapor pressure of a $0.05 \mathrm{M}$ aqueous solution of $\mathrm{HCN}$ is 4.65 torr at $25^{\circ} \mathrm{C}$ (Bodek et al. 1988). $\mathrm{HCN}$ (the only volatile form of cyanide) is fairly toxic when inhaled. Cyanides (as $\mathrm{CN}$ ) have an occupational ceiling Final Rule Limit, a time . weighted average for an 8 -h day, of $5 \mathrm{mg} / \mathrm{m}^{3}$ (DOL 1990). Cyanide ion has a chronic and subchronic oral reference dose (essentially an allowable daily dose for the general population) of $0.02 \mathrm{mg} / \mathrm{kg} \cdot \mathrm{d}$ (EPA 1991). Because it does not appear that either cyanide salts or HCN was introduced into the building, the most likely source of cyanides would be hydrolysis of GA, but this process would most likely have resulted in exposure of the cyanide ion or HCN to conditions that would have led to its loss or destruction.

\subsubsection{Sulfides}

Inorganic sulfide salts are toxic when ingested and are converted to the gas hydrogen sulfide $\left(\mathrm{H}_{2} \mathrm{~S}\right)$ on acidification. The boiling point of $\mathrm{H}_{2} \mathrm{~S}$ is $-60.7^{\circ} \mathrm{C}$. The $\mathrm{pK}$ at $25^{\circ} \mathrm{C}$ is 7.05 , so that $\mathrm{H}_{2} \mathrm{~S}$ is about half-dissociated at $\mathrm{pH}$. A $0.05 \mathrm{M}$ solution at $\mathrm{pH} 7$ and $20^{\circ} \mathrm{C}$ would have an $\mathrm{H}_{2} \mathrm{~S}$ partial vapor pressure of about 165 torr (Bodek et al. 1988). $\mathrm{H}_{2} \mathrm{~S}$ has an occupational ceiling Final Rule Limit of $14 \mathrm{mg} / \mathrm{m}^{3}$, a subchronic inhalation reference concentration of $9 \times 10^{-3} \mathrm{mg} / \mathrm{m}^{3}$ (chronic $9 \times 10^{-4} \mathrm{mg} / \mathrm{m}^{3}$ ) for the general population, and a subchronic oral reference dose of $0.03 \mathrm{mg} / \mathrm{kg} \cdot \mathrm{d}$ (chronic $0.003 \mathrm{mg} / \mathrm{kg} \cdot \mathrm{d}$ ) for the general population (DOL 1990, EPA 1991). The human nose is so sensitive to hydrogen sulfide (the only volatile form of sulfide) that an unrestrained individual would ordinarily not permit himself to be exposed long enough to get a lethal dose of this nauseating gas. Hydrogen sulfide has an odor threshold of about $3 \times 10^{-3} \mathrm{mg} / \mathrm{m}^{3}$ (Bodek et al. 1988). Sulfides were identified among potential contaminants of Building E5032 as "residual from mustard" (Borland et al. 1989). The term "sulfides" commonly means inorganic sulfides, but the information source might have meant organic sulfides, in particular the relatively harmless thiodiglycol (a hydrolysis product of mustard "gas"). This 
substance has the very high oral median lethal dose in rats of $6,610 \mathrm{mg} / \mathrm{kg}$, and -- as far as can be ascertained -- has never been suspected of causing toxic effects in man. The degree of stability and the degradation products of thiodiglycol in the environment are not known; its structure suggests that it should undergo facile biodegradation.

\subsubsection{Asbestos}

State and federal regulations regarding asbestos are readily available; licensed asbestos removers should be hired to strip pipes and vessels of friable asbestos insulation in buildings scheduled for renovation or demolition (Maryland Department of the Environment 1990, DOL 1986). The building must be kept under negative pressuie, and effluent air must be passed through a particle filter during asbestos removal.

\subsubsection{Bird Feces}

Old unsealed buildings (or dense thickets of trees) make attractive roosting or nesting places for gregarious birds, such as pigeons. Over time, layers of $m^{\prime}$ ist bird droppings can accumulate to depths of several inches or even feet. Such material is an deal incubation bed for pathogenic fungi such as Histoplasma capsulatum (the agent for histoplasmosis) or Filobasidiella neoformans (also known as Cryptococcus neoformans or Torula hystolytica, the etiologic agent for cryptococcosis) (Berkow 198\%, Emmons 1955). A number of years ago, three Post Engineer personnel at Fort Detrick, Frederick, Md., were exposed by inhalation to bird feces at an unused building and became extremely ill with what was first diagnosed as histoplasmosis but was later attributed to Cryptococcus neoformans (Spencer 1991). Cryptococcosis is a very serious disease; it can cause such central nervous system lesions as diffuse meningitis, meningeal granulomas, infarcts, and intensive tissue destruction; pulmonary and other symptoms can also occur (Berkow 1987). Dust masks are insufficient protection; self-contained breathing apparatus or full-face respirators are recommended for workers entering areas of possible exposure. Bird droppings must be removed from a building before other work is done. They can be disinfected with formaldehyde; drying will also inactivate the pathogens (Spencer 1991). It does not appear that the accumulation of bird droppings in Building E5032 is sufficient to cause serious concern, since the accumulation is probably too scant to maintain a moisture level favorable for growth of the pathogens of interest. Nevertheless, it might be prudent to provide maximum recommended protection to workers during the predemolition cleanup phase.

\subsubsection{Lead}

This metal will be considered later, if necessary. 


\subsection{Probability of Encountering Substances of Concern during Demolition}

The information provided above indicates that sampling is unlikely to reveal even traces of the toxicants of concern.

If WP is present at all in Building E5032, the most likely compartments would be those that could protect it from air, namely closed vessels or pipes, overlying water, or deep anoxic soil. All but the last will be probed. If these compartments are clean, then demolition should proceed without further concern. In the unlikely event that a pocket of WP were disturbed, smoke would alert personnel; toxic exposure, even for those not wearing protective gear, would be momentary and certainly not chronic. It is difficult to envision a means whereby WP could penetrate a porous structural surface such as concrete because spilled WP would not have been in liquid form for extended periods, either molten or in solution. If it did penetrate a surface, the diffusion of oxygen into the pores would soon lead to oxidation of the WP. Only fairly large masses of WP are capable of surviving chemical degradation in dry soil over a period of years; WP at levels of parts per million or per thousand would disappear.

If HD is present at all in Building E5032, it would also tend to be found in closed vessels or pipes or -- if in contact with moisture (e.g., at the bottom of a sump) -- in masses large enough to form protective layers of the polymeric products of partial hydrolysis. Low concentrations of mustard exposed to water would undergo extremely rapid hydrolysis to the harmless product thiodiglycol. As discussed above, HD and concrete were demonstrated to be chemically incompatible; there is therefore no reason to believe that $\mathrm{HD}$ would be released from within the pores of concrete as a result of breaking floors or walls of that material into transportable pieces.

The nerve agent GA is fairly water-soluble, and once dissolved it would decompose within a few hours or days. It would only remain intact if it were sealed in a container with stabilizing agents. Thus, it could only be present in Building E5032 if contained in a suitable vessel.

Triethylaluminum cannot tolerate any exposure to air or moisture. The only possibility that it could be found in Building E5032 would be if it were in the valved metal cylinder in which it was originally shipped.

Thermite, a mixtur of two high-melting nontoxic solid particulate materials, ceased to be handled in Building E5032 about 70 years ago. Any remnants of the aluminum powder in this material -- in inaccessible corners or in sediments in sumps -- would have been largely converted to harmless aluminum oxide.

The historic presence of cyanides in Building E5032 is at best conjectural. This guess is based on the idea that the nerve agent GA might have been released and hydrolyzed. However, hydrolysis of GA, if conducted under neutral or acidic conditions, would produce cyanide in the form of HCN gas, which would quickly disperse. Cyanide ion, if formed by hydrolysis of GA in a quite basic solution and maintained in such a solution, would undergo slow hydrolysis (with a half-life of about one year). Perhaps, if such a solution were to evaporate (say, in a matter of days), the residual cyanide salts could last for quite a while. After cleanun of the building, 
however, there would be few places where cyanide could remain if, in fact, it was ever formed under conditions conducive to its preservation.

The nomination of sulfides as "residuals fron mustard" is even more problematical. It is difficult to envision an association of mustard (HD) with inorganic sulfides, which are generally implied when the term is used without the qualifier "organic." If inorganic sulfides were in fact associated with mustard (HD), and were somehow dissolved in water, they would tend to form hydrogen sulfide and volatilize except at extremely high $\mathrm{pH}$; moreover, under aerobic conditions, even at high $\mathrm{pH}$, they would be oxidized by dissolved oxygen to higher -- and less toxic -- valence states. An alternative interpretation of "sulfides" is the organic sulfide product of complete hydrolysis of mustard (itself an organic sulfide), namely thiodiglycol. Thiodiglycol is quite watersoluble and has a relatively low vapor pressure and very low toxicity. Its presence in the water of a sump might be a clue to the nearby existence of $\mathrm{HD}$ (hence, analysis for it is appropriate) but would have little significance on its own account.

If the cleanup of asbestos is carried out competently, remaining levels will conform to regulatory requirements and should be of no further concern.

If openings in Building E5032 used by birds are properly sealed and the building is swept clean by workers using respiratory protection, bird feces may be eliminated from further consideration as a contaminant.

\subsection{Development of Reference Doses for Potential Contaminants for Use in Risk Assessment}

Occupational RfDs (reference doses in $\mathrm{mg} / \mathrm{kg} \cdot \mathrm{d}$ ) for WP, cyanide, and sulfide have been calculated from the occupational air concentration limits known as Final Rule Limits that were presented in Section 3.2 (DOL 1990). The Final Rule Limit values were multiplied by $20 \mathrm{~m}^{3}$ per 8-h workday, a breathing rate corresponding to light-to-moderate activity (EPA 1988), and divided by an adult body weight of $70 \mathrm{~kg}$ to obtain RfDs. U.S. Army-recommended subchronic occupational air concentration limits for HD and GA presented in Section 3.2 have been treated similarly to provide reference doses for these compounds.

A general population RfD for WP has been derived in Section 3.2.1. General population RfDs for $\mathrm{HD}$ and GA have been derived from Army-recommended air concentration limits (values presented in Section 3.2). The latter were multiplied by $25 \mathrm{~m}^{3}$ per 24 -h day, a breathing rate corresponding to a combination of light work and resting, and divided by an adult body weight of $70 \mathrm{~kg}$ (EPA 1988). An oral general population reference dose for cyanide was used for both oral and inhalation routes (EPA 1991). A general population RfD -- to be used for the inhalation route -- was derived for hydrogen sulfide by multiplying the inhalation reference concentration, a type of air concentration limit, by $25 \mathrm{~m}^{3} / \mathrm{d}$ and dividing by $70 \mathrm{~kg}$, but there was a different number available for oral (and for the present application, percutaneous) toxicity (EPA 1991).

The RfDs just described are summarized in Table 1. Except where explicitly stated, no attempt is made to differentiate betweon toxicity by differenti routes or to aujust for the fraction 
absorbed by different routes. Such information is often not available, and the proportion swallowed -- compared with that lodged in the lungs -- is variable.

TABLE 1 Occupational Reference Doses for Potential Contaminants

\begin{tabular}{|c|c|c|c|c|}
\hline Contaminant & $\begin{array}{c}\text { Occupational } \\
\text { Inhalation } \\
\text { Concentration } \\
\text { Limit } \\
\left(\mathrm{mg} / \mathrm{m}^{3}\right)\end{array}$ & $\begin{array}{c}\text { Occupational } \\
\text { Reference } \\
\text { Dose } \\
(\mathrm{mg} / \mathrm{kg} \cdot \mathrm{d})\end{array}$ & $\begin{array}{c}\text { General } \\
\text { Population } \\
\text { Subchronic } \\
\text { Inhalation } \\
\text { Concentration } \\
\text { Limit } \\
\left(\mathrm{mg} / \mathrm{m}^{3}\right)\end{array}$ & $\begin{array}{l}\text { General } \\
\text { Population } \\
\text { Subchronic } \\
\text { Reference } \\
\text { Dose } \\
(\mathrm{mg} / \mathrm{kg} \cdot \mathrm{d})\end{array}$ \\
\hline $\begin{array}{l}\text { WP } \\
\text { HD } \\
\text { GA } \\
\text { Cyanide } \\
\text { Sulfide } \\
\quad\left(\text { or } \mathrm{H}_{2} \mathrm{~S}\right)\end{array}$ & $\begin{array}{l}0.1 \\
0.003 \\
0.0002 \\
5.0 \\
14.0\end{array}$ & $\begin{array}{c}0.0286 \\
8.57 \times 10^{-4} \\
5.71 \times 10^{-5} \\
1.43 \\
4.00\end{array}$ & $\begin{array}{c}1.0 \times 10.4 \\
3.0 \times 10^{-6} \\
0.056^{b} \\
0.009\end{array}$ & $\begin{array}{c}1.50 \times 10^{-4} \\
3.57 \times 10^{-5} \\
1.07 \times 10^{-6} \\
0.02^{\mathrm{c}} \\
0.0032^{\mathrm{d}} \\
0.030^{\mathrm{c}}\end{array}$ \\
\hline
\end{tabular}

aNo value available.

bBack-calculated from the general subchronic reference dose (RfD).

COral (EPA 1991). .

dinhalation RfD derived from the general population subchronic inhalation concentration limit (EPA 1991). 


\section{Decommissioning Concepts}

\subsection{Decommissioning Concepts that Had Been Considered for Building E5625}

Methodologies considered for the decommissioning of another building, Aberdeen Proving Ground Building E5625, have been reviewed carefully as part of the present evaluation of potential risk posed by the demolition of Building E5032 (Carpenter and Hill 1988). It would appear that the proponents of these methodologies originally expected, for lack of definitive historical or analytical information, rather significant concentrations of toxicants throughout Building E5625. Their first 13 concepts therefore involved extreme measures to contain the building during demolition (thereby avoiding toxic releases) and to decontanninate the debris produced by demolition. Only their 14th concept (Concept $N$ ) was "based on the assumption that little, if any, chemical agent contamination exists within the structures of the building." At this point they acknowledged that "chemical agents are not expected to desorb from building materials in sufficient quantities to cause an impact on human health or the environment."

Each of the first 13 concepss (A through $\mathrm{M}$ ) involved containment, demolition, and decontamination. Containment could be accomplished through construction of a metal enclosing building (New Building concept), construction of a flexible bubble enclosure (impractical), or thoroughly sealing the building's exterior surfaces. Demolition methods were characterized as selective (labor-intensive, with various types of equiprnent) or gross (with wrecking balls and clamshell buckets). The three proposed decontamination modalities were chemical decontamination, incineration, and hot-gas decontamination; the third option, though considered in detail by the authors of the report, is not an approved methodology. The 14th concept $(\mathrm{N})$, using no containment, involved gross demolition (less expensive than, but with a lesser degree of control than, selective demolition; see below) and incineration. The authors selected five concepts for detailed examination.

\begin{tabular}{|c|c|c|c|}
\hline Concept & Containment & Deinolition & Decontamination \\
\hline A & New Building & Selective & Chemical \\
\hline B & New Building & Selective & Incineration \\
\hline $\mathrm{J}$ & New Building & Gross & Incineration \\
\hline $\mathrm{K}$ & Sealing & Gross & Hot Gas \\
\hline $\mathbf{N}$ & None & Gross & Incineration \\
\hline
\end{tabular}

The methods of containment addressed for Building E5625 do not appear particularly useful for the decommissioning of Building E5032. A metal enclosing building would be an unnecessary expense. The sealing of exterior surfaces (Concept $\mathrm{K}_{n}$ ) with a sealant material "resistant to contaminant permeation and not . . . degraded by their presence," as well as not affected "by environmental forces, such as rain, wind or temperature extremes," represents a costly extreme of a basically practical idea. Semirigid fiberglass insulation boards designed for operating temperatures of $450^{\circ} \mathrm{C}$ were recommended for Concept $\mathrm{K}$. 
Carpenter and Hill (1988) described both selective and gross demolition methods in detail, and much can be learned from their discussions as well as from those of Murthy and Chatterjee (1976). In selective demolition, as applied to the multistory Building E5625, equipment integral to the building (including processing equipment, ventilation systems, and presumably ductwork and pipes) would be removed first, with cutting torches, if necessary. One- or two-story sections of the building would then be torn down with the aid of a backhoe, starting with the roof. Both backhoes and impact rams can break concrete, though a wrecking ball might be needed to deal with foundations of thick concrete. Exposed steel beams could be sectioned with hydraulic shears or cutting torches. Sumps would be removed next. Light machinery would be brought to the higher floors of the building to dismantle the upper stories. This step might entail punching a hole in the roof with a wrecking ball and lifting machinery in through the hole to the top floor. If the floors would not support crews and demolition equipment, lightweight equipment (such as jackhammers and diamond-tipped cutting tools) could be employed. Crews and equipment would be elevated on work platforms supported by telescoping hydraulic booms. In addition to the wrecking balls (used very selectively), impact rams (including jackhammers), cutting torches, hydraulic shears, diamond-tipped cutting tools, and backhoes mentioned above, good use might sometimes be made of hydraulically actuated breakers (for splitting brittle materials such as unreinforced concrete), flame-cutting equipment (for extremely thick or reinforced concrete), and high-pressure water jets (which are expensive and require strong operators to control them).

Because of the size of Building E5625, along with its planned containment, gross demolition under Concept $\mathrm{J}$ would require a gantry crane inside the metal enclosing building for use of a wrecking ball and/or a clamshell bucket. For either Concept $\mathrm{K}$ (in which hot-gas decontamination is considered to render the building safe before gross demolition) or Concept $\mathrm{N}$, a boom crane equipped with a wrecking ball appears to be the demolition equipment of choice. A clamshell bucket (replacing the wrecking ball), front-end loaders, and backhoes would be used to remove the debris. Cutting torches might be required to section steel beams. Gross demolition is approximately one-fifth as expensive as selective demolition, but it would generate more dust and be less easily controlled.

If hazardous levels of toxic substances had been found in the building, incineration or chemical methods of decontamination might have proved necessary. However, it appears that the authors seemed to think it desirable to decontaminate rubble from the building even if no significant levels of toxicants were found (Carpenter and Hill 1988).

\subsection{Decommissioning Concepts for Building E5032}

It is assumed that spills of toxic liquids, including solutions, would have been the most likely source of contamination of porous materials in the building. Thus, aside from sumps, pipes, or closed vessels, concrete floors (followed by the lower portions of partitions or walls) are most likely to contain contaminants. Regardless of whether or not evidence of contamination is found, it migh: be prudent to plan floor removal that would minimize exposure of people outside the building to generated dust or vapor. 
Because Building E5032 is a one-story building, it should be possible to section and remove most of the floor before violating the integrity of the sealed sides and roof. Sealing and negative pressure, along with particulate filters, which should have been installed for asbestos removal as required by regulation, would be maintained. It would be well to add carbon filters to remove toxic vapors during the period when the floor is sectioned or otherwise broken up and until the sections or rubble is removed. Dust would be suppressed by water mists or sprays. Depending on the nature of the floor, the applicable floor-removal method generating the least amount of dust should be applied. Because of the lack of information on dust concentrations generated indoors under the removal conditions, the dust exposure level used in the sealed-building calculations of acceptable contaminant concentrations in concrete (Section 3.4) will be presented as a unit concentration (i.e., $1 \mathrm{mg} / \mathrm{m}^{3}$ ). Should the sealed-building concept be adopted, dust levels would have to be measured early in the course of the work and acceptable concentrations in the concrete recalculated to scale. The assumption of a unit concentration circumvents the question of how to derive emission rates for sealed-building occupational exposures, replacing it with the need to take on-site measurements. In a second approach, a plausible level of dust generated by a jackhammer will be considered.

In addition to the sealed-building floor-removal concept, a more conventional kind of building demolition will be considered. In this scenario the roof and walls would be broken by a wrecking ball. Debris would be frequently decontaminated (if necessary) and hauled away. Sumps and drains would then be removed. Lastly, the concrete floor would be broken up with a wrecking ball or backhoe -- or possibly with less dust generation by a more selective technique -depending on whether the concrete contained reinforcing rods. 


\section{Occupational Risk Assessment}

\subsection{Inhalation of Respirable Dust and, Where Applicable, Vapor}

Two scenarios are envisioned in connection with potential occupational exposure to contaminant-laden inhalable particles and contaminant vapors. In the first scenario, the walls and roof are sealed and intact, and air is exhausted through a suitable filter. Thus, the public would be completely protected even if there were significant contamination. One floor-removal methodology for this scenario involves the use of a wetted diamond saw to cut the concrete floor -- presumably the main source of contaminants -- into blocks that can be packaged, if necessary, for safe shipment to a hazardous waste landfill. The other involves more conventional breakup with an impact ram (such as a jackhammer), though with wetting down with water to minimize the emission of dust. As explained in Section 4.2, the assumption is that the dust level will be $1 \mathrm{mg} / \mathrm{m}^{3}$; however, if the sealed-building approach is adopted, on-site dust measurements should be used to revise the dust exposure estimates based on this assumption. In the second scenario, impact rams would be used to remove the floor in open air.

\subsubsection{Scenario I}

In Scenario I, the building is sealed, and a wetted diamond saw or impact ram is used to remove the floor.

\subsubsection{Reasonable General Assumptions}

The concrete floor of Building E5032 is not more than $1 \mathrm{ft}$ thick. It has an area of $76.67 \times 55=4,217 \mathrm{ft}^{2}$ and a density of $85 \mathrm{lb} / \mathrm{ft}^{3}$. Thus, the floor's mass is about $1 \times 4,217 \times 85 / 2,000=179$ tons. The ceiling is about $17 \mathrm{ft}$ high, so (assuming early removal of interior walls and partitions) the interior volume should be about $71,700 \mathrm{ft}^{3}$.

If a water-cooled diamond-tipped saw is used, blocks of the concrete floor will be cut to dimensions that permit containment in 55 -gal drums, namely $3 \mathrm{ft} \times 1.5 \mathrm{ft} \times 1 \mathrm{ft}$ thick; the blocks should weigh about $383 \mathrm{lb}$ each. For the floor area involved and the width of the blocks, the total length of saw cuts should be $4,217 \mathrm{ft}$. The width of cuts by the water-cooled diamond-tipped saw is assumed to be $0.01 \mathrm{ft}$. Thus, the volume of pulverized concrete should be $42 \mathrm{ft}^{3}$.

If impact rams are used, the work area should be sprayed with enough water to suppress dust emission effectively. During the cutting/removal operation, the ventilation system installed for asbestos removal will be kept operating, possibly with the addition of a charcoal filter to remove vapors, so that the air will undergo a complete change at least once an hour. Hence, during the course of cutting and removing the floor, there will be at least eight air changes per day. The cutting/removal operation will take place over 10 working days, so the air will be changed about 80 times. 


\subsubsection{Assumptions Regarding Inhalation of Suspended Particles}

Workers will have either no respiratory protection or the uncertain protection of dust masks. The latter will be mandatory for dust levels above $15 \mathrm{mg} / \mathrm{m}^{3}$ (DOL 1990). The breathing rate (higher end of moderate exercise) is $20 \mathrm{~m}^{3}$ per 8 -h workday (EPA 1988).

The rate of vapor emission from newly exposed concrete surfaces, other than from suspended particles, will be negligible. Emissions from such particles are already accounted for in most cases, since what goes into the vapor form is subtracted from the amount contained in the suspended particulates.

Although the larger inhaled suspended particles may not reach the lungs, they will be swallowed; contaminants are therefore presumed to be $100 \%$ absorbed.

\subsubsection{Toxicant Exposure from Inhaled Particles at the Assumed Dust Level in Air of $1 \mathrm{mg} / \mathrm{m}^{3}$ and a Second Approach}

An average dust concentration of $1 \mathrm{mg} / \mathrm{m}^{3}$ within the building is assumed, as explained above; however, the calculation can also be carried out with any actual concentration. At the assumed value, an unprotected worker could inhale $1 \mathrm{mg} / \mathrm{m}^{3} \times 20 \mathrm{~m}^{3} / \mathrm{d}=20 \mathrm{mg} / \mathrm{d}$ of total suspended particulates. A concentration of a toxicant in the concrete of $1 \mathrm{mg} / \mathrm{kg}(1 \mathrm{ppm})$ would result in an exposure of $2.0 \times 10^{-5} \mathrm{mg} / \mathrm{d}$ per person to the toxicant or, for a $70-\mathrm{kg}$ person, $2.86 \times 10^{-7} \mathrm{mg} / \mathrm{kg} \cdot \mathrm{d}$.

A second dust inhalation approach involves calculating an average particle level in the breathing zone of the most exposed worker, namely a jackhammer operator. In research dealing with dust generated from sandstone, Scharf (1967) described a water attachment for jackhammers (a class of impact rams) that effected a considerable reduction of dust particles in the breatiing zone. He reported that without the water delivered by this device the dust concentration was $6.4 \times 10^{7}$ particles smaller than $5 \mu \mathrm{m}$. If the particle mass is based on an assumed diameter of $4 \mu \mathrm{m}$ and a density of $85 \mathrm{lb} / \mathrm{ft}^{3}\left(1.36 \times 10^{8} \mathrm{mg} / \mathrm{m}^{3}\right)$, the mass concentration of particles smaller than $5 \mu \mathrm{m}$ is calculated as $104 \mathrm{mg} / \mathrm{m}^{3}$. With the wetting device, the concentration is reduced to $2.99 \times 10^{6}$ particles smaller than $5 \mu \mathrm{m}$, for which an estimated mass concentration of $4.9 \mathrm{mg} / \mathrm{m}^{3}$ results. Because particles larger than $5 \mu \mathrm{m}$ as well as smaller particles can be vehicles for toxic chemicals, the estinated mass is approximately doubled here, to give a dust concentration of $10 \mathrm{mg} / \mathrm{m}^{3}$ (and about $200 \mathrm{mg} / \mathrm{m}^{3}$ for the total level of dust without the water attachment). Occupational Safety and Health Administration (OSHA) regulations require appropriate respiratory protection for all dust levels in excess of $15 \mathrm{mg} / \mathrm{m}^{3}$ (DOL 1990); thus, it is very likely that a water attachment such as that described by Scharf would be employed. This step would permit regulatory compliance without requiring personnel to wear dust filters or other respiratory protection. It is assumed that a laborer would operate a jackhammer only about five hours daily. Thus, it is estimated that the worker is exposed, on average, to $6.25 \mathrm{mg} / \mathrm{m}^{3}$ during the workday. 


\subsubsection{Permissible Toxicant Levels in the Concrete Floors}

The acceptable level of a contaminant $(\mathrm{mg} / \mathrm{kg}$ ) in concrete is calculated by dividing the reference dose (see Section 3.4) by the predicted exposure corresponding to $1 \mathrm{mg} / \mathrm{kg}$ in the concrete. Alternatively, the ratio of the acceptable air concentration to the predicted air concentration generated by $1 \mathrm{mg} / \mathrm{kg}$ of contaminant in the concrete gives the acceptable level of contaminant in the concrete. Both calculations are used in the remainder of this document.

For WP, which has an RfD of $0.0286 \mathrm{mg} / \mathrm{kg} \cdot \mathrm{d}$, the calculated acceptable level in concrete is $0.0286 /\left(2.86 \times 10^{-7}\right)=10(,, 000 \mathrm{~m} / \mathrm{kg}$. Since this figure represents $10 \%$ of the concrete, it is not a realistic goal in itself but is a suitable number to combine with calculations for other exposure routes, as shown in Section 7. Moreover, it permits easy calculation of allowable levels in the concrete corresponding to higher airborne dust concentrations. The second approach described above assumes that a laborer would be exposed to an average dust concentration of $6.25 \mathrm{mg} / \mathrm{m}^{3}$, which would lead to an acceptable level of WP in the concrete of $16,000 \mathrm{mg} / \mathrm{kg}$.

For $\mathrm{HD}$, which has an $\mathrm{RfD}$ of $8.57 \times 10^{-4} \mathrm{mg} / \mathrm{kg} \cdot \mathrm{d}$, the calculated acceptable concentration in concrete is $3,000 \mathrm{mg} / \mathrm{kg}$. Since HD hydrolyzes so rapidly in water (and since its Henry's Litw constant is lower than that of WP), volatilization from the wetted pulverized concrete is not envisioned. If anything, because of hydrolysis, the concentration allowed here is probably lower than necessary. The second approach described above assumes that a laborer would be exposed to an average dust concentration of $6.25 \mathrm{mg} / \mathrm{m}^{3}$, which would lead to an acceptable level of $H D$ in the concrete of $480 \mathrm{mg} / \mathrm{kg}$.

For GA, which has an RfD of $5.71 \times 10^{-5} \mathrm{mg} / \mathrm{kg} \cdot \mathrm{d}$, the acceptable level in concrete is calculated as $200 \mathrm{mg} / \mathrm{kg}$. The low Henry's Law constant (due primarily to the high solubility of GA in water) ensures that this compound will tend to remain in the aqueous phase (rather than evaporate) and eventually undergo hydrolysis. The assumption (in the second approach) that a laborer would be exposed to an average dust concentration of $6.25 \mathrm{mg} / \mathrm{m}^{3}$ leads to an acceptable level of GA in the concrete of $32 \mathrm{mg} / \mathrm{kg}$.

The RfD for cyanide ion is $1.43 \mathrm{mg} / \mathrm{kg} \cdot \mathrm{d}$, whence it is calculated that any concentration of cyanide in the concrete (inhaled dust only) would be acceptable. As with WP, this finding would not be realistic in itself; it indicates that relatively high concentrations of the contaminant would be safe if exposure occurred solely by the dust inhalation route and the dust concentration were $1 \mathrm{mg} / \mathrm{m}^{3}$. (For an airborne dust concentration of $10 \mathrm{mg} / \mathrm{m}^{3}, 500,000 \mathrm{mg} / \mathrm{kg}$ is calculated as an acceptable value.)

The RfD for hydrogen sulfide is $4.0 \mathrm{mg} / \mathrm{kg} \cdot \mathrm{d}$, which indicates that any level would be acceptable in concrete under the assumed conditions, as for cyanide. (For an airborne dust concentration of $15 \mathrm{mg} / \mathrm{m}^{3}$, the calculated acceptable concentration would be $932,000 \mathrm{mg} / \mathrm{kg}$.) 


\subsubsection{A Special Concern Regarding Cyanide and Sulfide}

Aqueous solutions of cyanide and sulfide salts resulting from the extraction of these salts from concrete are capable of emitting vapors of hydrogen cyanide or hydrogen sulfide, especially from air-dispersed water droplets. Hydrogen sulfide should evolve especially rapidly because of its relatively high vapor pressure above water (about 35 times higher than that of $\mathrm{HCN}$ at $\mathrm{pH} 7$ ). As an example, some of the assumptions presented above may be used to estimate the total emissions from the pulverized concrete generated by the diamond-tipped saw. A released vapor concentration, $c_{v}$, from pulverized concrete initially containing $1 \mathrm{mg} / \mathrm{kg}$ of cyanide is calculated as follows:

$$
\begin{aligned}
c_{v}= & \left(42 \mathrm{ft}^{3} \times 85 \mathrm{lb} / \mathrm{ft}^{3} \times 454,000 \mathrm{mg} / \mathrm{lb} \times 10^{-6} \mathrm{~kg} / \mathrm{kg}\right) \\
& +\left(2,030 \mathrm{~m}^{3} \times 80 \text { air changes }\right) \\
= & 0.01 \mathrm{mg} / \mathrm{m}^{3}
\end{aligned}
$$

For an occupational concentration limit of $5 \mathrm{mg} / \mathrm{m}^{3}$, the acceptable concentration of cyanide (as HCN) in the concrete would thus be $5 / 0.0100 \mathrm{mg} / \mathrm{kg}(500 \mathrm{mg} / \mathrm{kg}$ ). (This method is a variant of the approach used above, in that it uses a ratio of concentrations in the air rather than a dose ratio.) For an occupational concentration limit of $14 \mathrm{mg} / \mathrm{m}^{3}$, the acceptable concentration of sulfide (as $\mathrm{H}_{2} \mathrm{~S}$ ) in the concrete would be $14 / 0.0100 \mathrm{mg} / \mathrm{kg}(1,400 \mathrm{mg} / \mathrm{kg})$. Such numbers are independent of the measured concentration of particulates in the work-site air.

An estimate for the vapor concentrations that might be generated with impact rams may also be derived. First, it is estimated that, "Generally, about $1 \%$ of the material demolished could become particulate emissions unless suitable measures to prevent dust formation during wrecking were instituted" (Murthy and Chatterjee 1976). Although more than this fraction of the rubble might be extractable with water, it is doubtful that the amount of spray used to control dust emission would be sufficient to mobilize chemicals contained in the larger particles. Thus, the estimate of vapor emission, $c_{v}$, from concrete dust containing $1 \mathrm{mg} / \mathrm{kg}$ of a contaminant becomes:

$$
\begin{aligned}
c_{v} & =0.01 \times 179 \text { tons } \times 907.2 \mathrm{~kg} / \mathrm{ton} \times 1 \mathrm{mg} / \mathrm{kg} \times 1 /\left(2,030 \mathrm{~m}^{3} \times 80\right) \\
& =0.01 \mathrm{mg} / \mathrm{m}^{3}
\end{aligned}
$$

This number is the same value as that derived for the diamond-tipped saw estimate and leads to identical criteria of $500 \mathrm{mg} / \mathrm{kg}$ for cyanide and $1,400 \mathrm{mg} / \mathrm{kg}$ for sulfide.

\subsubsection{Scenario II}

In Scenario II, impact rams in open air are used to remove the floor. The diamond saw method is not treated here. Dispersion of dust and vapors by the wind should keep contaminant concentrations caused by use of impact rams quite low. 


\subsubsection{Reasonable Assumptions as to Generation of Breathable Particles}

The following argument is based on an equation found after limited search for a suitable model. It may very well understate the emission rate. A better model is currently being sought. If it appears that the emission rate is significantly higher than that shown here, this section will be modified as necessary.

The concrete floor of Building E5032 is not more than $1 \mathrm{ft}$ thick. It has an area of $4,217 \mathrm{ft}^{2}$ and a density of $85 \mathrm{lb} / \mathrm{ft}^{3}$. Thus, the floor's mass is about $1 \times 4,217 \times 85 / 2,000=179$ tons.

The emission factor proposed by Grelinger et al. (1988) for dismemberment and collapse of a structure, probably a more violent process than the selective demolition contemplated for the floor of Building E5032, is the following:

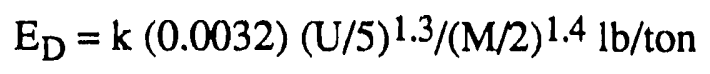

Here $\mathrm{k}=0.35$ for $\mathrm{PM}_{10}$. However, this factor is omitted -- thereby focusing on total suspended particulates (TSP) -- when chemical toxicants are at issue, as in the present case. The value of $U$ is given in $\mathrm{mi} / \mathrm{h}$. The term $U=$ mean wind speed, assumed here to be $4.2 \mathrm{~m} / \mathrm{s}$ (the mean wind speed for the Baltimore area) or $9.4 \mathrm{mi} / \mathrm{h}$ (Cowherd et al. 1984), and $\mathrm{M}=$ material moisture content (default value $2 \%$ ).

Hence $E_{D}=0.0073 \mathrm{lb} /$ ton or $3,300 \mathrm{mg}$ of respirable particles per ton, for a total of $3,300 \times 179 \mathrm{mg}=591,000 \mathrm{mg}$ of respirable particles for the entire floor removal. However, it may be assumed in the present case that particle emission will be largely controlled by water sprays -- say $80 \%$-- so that the total emission will be reduced to $0.2 \times 591,000=118,000 \mathrm{mg}$.

\subsubsection{Conclusions as to the Air Concentration of Suspended Particles}

For this calculation, the building width is $55 \mathrm{ft}(16.8 \mathrm{~m})$ and the length is $76.67 \mathrm{ft}$ $(23.4 \mathrm{~m})$; the height of the mixing zone is very conservatively selected as $2 \mathrm{~m}$ (since at $1 \mathrm{~m}$ it would not reach the breathing zone). With an average wind speed of $4.2 \mathrm{~m} / \mathrm{s}$, wind traversing the length or the building would provide an air change every $5.6 \mathrm{~s}$, or 51,000 changes in the 30 hours the demolition would require. The mass of respirable particles per air change would he $118,000 / 51,000=2.31 \mathrm{mg}$ in a $16.8 \mathrm{~m} \times 23.4 \mathrm{~m} \times 2 \mathrm{~m}$ hox, giving an approximate average concentration of $0.00294 \mathrm{mg} / \mathrm{m}^{3}$ over 80 work hours.

\subsubsection{Assumptions Regarding Inhalation of Suspended Particles}

These assumptions are similar to those presented for Scenario I. 


\subsubsection{Toxicant Exposure trom Inhaled Particles and a Second Approach}

An unprotected worker might inhale $0.00294 \mathrm{mg} / \mathrm{m}^{3} \times 20 \mathrm{~m}^{3} / \mathrm{d}=0.0588 \mathrm{mg} / \mathrm{d}$ of suspended particulates. A concentration of a toxicant in the concrete of $1 \mathrm{mg} / \mathrm{kg}(1 \mathrm{ppm})$ would result in exposure of $5.88 \times 10^{-8} \mathrm{mg} / \mathrm{d}$ per person of the coxicant or, for a $70-\mathrm{kg}$ person, $8.40 \times 10^{-10} \mathrm{mg} / \mathrm{kg} \cdot \mathrm{d}$.

The second approach used for Scenario I is considered applicable in the present case. It leads to the same acceptable levels for the dust inhalation pathway as in Scenario I because, except in a strong wind, the breathing zone dust concentrations should be about the same. Thus, the effective average dust concentration is estimated at $6.25 \mathrm{mg} / \mathrm{m}^{3}$.

\subsubsection{Permissible Toxicant Levels in the Concrete Floors}

For WP (see Section 3.4), the occupational RfD is $0.0286 \mathrm{mg} / \mathrm{kg} \cdot \mathrm{d}$, from which it is calculated $\left(\mathrm{RfD} /\left[8.40 \times 10^{-10}\right]\right)$ that any WP level in the concrete would be acceptable. The second approach assumes that a laborer would be exposed to an average dust concentration of $6.25 \mathrm{mg} / \mathrm{m}^{3}$, which would lead to an acceptatle level of WP in the concrete of $16,000 \mathrm{mg} / \mathrm{kg}$.

For HD, the occupational RfD is $8.57 \times 10^{-4} \mathrm{mg} / \mathrm{kg} \cdot \mathrm{d}$, from which it is calculated that any concentration in concrete would be allowable. The second approach and its assumptions lead to an acceptable level of HD in the concrete of $480 \mathrm{mg} / \mathrm{kg}$.

The occupational RfD for GA is $5.71 \times 10^{-5} \mathrm{mg} / \mathrm{kg} \cdot \mathrm{d}$. The methods presented above can be used to calculate an acceptable occupational criterion for concrete of $68,000 \mathrm{mg} / \mathrm{kg}$. The second approach leads to an acceptable level of WP in the concrete of $32 \mathrm{mg} / \mathrm{kg}$.

The occupational RfD for cyanide ion is $1.43 \mathrm{mg} / \mathrm{kg} \cdot \mathrm{d}$, whence it can be calculated that any level of cyanide in the concrete would be acceptable for workers or the general population.

The occupational RfD for hydrogen sulfide is $0.0032 \mathrm{mg} / \mathrm{kg} \cdot \mathrm{d}$, whence it can be calculated that any level of sulfide in the concrete is acceptable for workers or the general population.

\subsubsection{A Special Concern Regarding Cyanide and Sulfide}

As in Section 5.1.1.5, it should be considered that aqueous solutions of cyanide and sulfide salts resulting from the extraction of these salts fr $\mathrm{m}$ concrete are capable of emitting vapori of hydrogen cyanide or hydrogen sulfide. Here, the same principles are used, except that the box volume is that of Section 5.1.2.2 (i.e., $16.8 \times 23.4 \times 2=786 \mathrm{~m}^{3}$ ), as is the number of air exchanges $(51,000)$. Hence, for the pulverized concrete generated by the diamond-tipped saw: 


$$
\begin{aligned}
c_{v}= & \left(42 \mathrm{ft}^{3} \times 85 \mathrm{lb} / \mathrm{ft}^{3} \times 454,000 \mathrm{mg} / \mathrm{lb} \times 10^{-6} \mathrm{~kg} / \mathrm{kg}\right) \\
& +\left(786 \mathrm{~m}^{3} \times 51,000 \text { air changes }\right) \\
= & 4.04 \times 10^{-5} \mathrm{mg} / \mathrm{m}^{3}
\end{aligned}
$$

As in Section 5.1.1.5, an estimate of the vapor concentraisons that might be generated with impact rams may also be derived. Here, the estimate of vapor emission, $c_{v}$, from concrete dust containing $1 \mathrm{mg} / \mathrm{kg}$ of a contaminant becomes:

$$
\begin{aligned}
c_{v}= & 0.01 \times 179 \text { tons } \times 907.2 \mathrm{~kg} / \text { ton } \times 1 \mathrm{mg} / \mathrm{kg} \\
& +\left(786 \mathrm{~m}^{3} \times 51,000 \text { air changes }\right) \\
= & 4.05 \times 10^{-5} \mathrm{mg} / \mathrm{m}^{3}
\end{aligned}
$$

This number is virtually the same as that derived in the diamond-tipped saw estimate; both lead to occupational criteria of $123,000 \mathrm{mg} / \mathrm{kg}$ for cyanide and $346,000 \mathrm{mg} / \mathrm{kg}$ for sulfide, regardless of the dust concentration in the air.

\subsection{Ingestion of Particulates}

This exposure route is calculated for both scenarios.

\subsubsection{Assumptions Regarding Ingestion of Soil and Dust}

Despite the rigorous hygienic discipline that should be practiced in the present circumstances, including wearing gloves and washing the hands before eating or smoking in a clean area, it will be assumed that a worker might ingest daily as much as $50 \mathrm{mg}$ of demolitiongenerated (mostly concrete) dust (compare Jernigan et al. 1991).

\subsubsection{Conclusions as to Toxicant Exposure by Ingestion}

At a concentration of a toxicant in the concrete of $1 \mathrm{mg} / \mathrm{kg}(1 \mathrm{ppm})$, daily ingestion of $50 \mathrm{mg}$ of pulverized concrete would provide a toxicant exposure of $5 \times 10^{-5} \mathrm{mg} / \mathrm{d}$ or, for a $70-\mathrm{kg}$ person, $7.14 \times 10^{-7} \mathrm{mg} / \mathrm{kg} \cdot \mathrm{d}$.

\subsubsection{Permissible Toxicant Levels In the Concrete Floors}

For WP (see Section 3.4), the occupational RfD is $0.0286 \mathrm{mg} / \mathrm{kg} \cdot \mathrm{d}$, from which the acceptable WP level in the concrete is calculated as $40,000 \mathrm{mg} / \mathrm{kg}$ (or $4 \%$ ). 
For $\mathrm{HD}$, the occupational RfD is $8.57 \times 10^{-4} \mathrm{mg} / \mathrm{kg} \cdot \mathrm{d}$, from which the acceptable level in concrete is calculated as $1,200 \mathrm{mg} / \mathrm{kg}$.

The occupational RfD for GA is $5.71 \times 10^{-5} \mathrm{mg} / \mathrm{kg} \cdot \mathrm{d}$, and the acceptable occupational criterion for concrete is calculated as $80 \mathrm{mg} / \mathrm{kg}$.

The occupational RfD for cyanide ion is $1.43 \mathrm{mg} / \mathrm{kg} \cdot \mathrm{d}$, and any level of cyanide in the concrete would be acceptable for workers.

The occupational RfD for sulfide is $4.00 \mathrm{mg} / \mathrm{kg} \cdot \mathrm{d}$, and any level of sulfide in the concrete is acceptable for workers.

\subsection{Dermal Exposure}

This exposure route is calculated for both scenarios.

\subsubsection{Assumptions Regarding Contact of Skin with Soil and Dust}

Despite the rigorous hygienic discipline that should be practiced in the present situation, including wearing long-sleeved shirts, gloves, and head covering, it will be assumed that a worker might have his head and hands uncovered. The total area of these body parts is approximately $0.2 \mathrm{~m}^{2}$ (EPA 1989a). An assumed soil loading on skin of $1.45 \mathrm{mg} / \mathrm{cm}^{2}$ (EPA 1988) thus implies a soil load of $2,900 \mathrm{mg} / \mathrm{d}$ per person. Although soil-borne compounds of very low vapor pressure in contact with skin are absorbed at the rate of about $1 \%$ in $12 \mathrm{~h}$ (Yang et al. 1989), it will be assumed here that for the compounds of interest the efficiency is $10 \%$.

\subsubsection{Conclusions as to Toxicant Exposure}

The dermal toxicant absorption rate for concrete dust contaminated with $1 \mathrm{mg} / \mathrm{kg}$ of a toxicant is calculated as $1 \times 0.1 \times 2,900 \times 10^{-6}+70=4.1 \times 10^{-6} \mathrm{mg} / \mathrm{kg} \cdot \mathrm{d}$ for a person weighing $70 \mathrm{~kg}$.

\subsubsection{Permissible Toxicant Levels in the Concrete Floors}

For WP (see Section 3.4), the occupational RfD is $0.0286 \mathrm{mg} / \mathrm{kg} \cdot \mathrm{d}$, from which the acceptable WP level in the concrete is calculated as $7,000 \mathrm{mg} / \mathrm{kg}$.

For HD, the occupational RfD is $8.57 \times 10^{-4} \mathrm{mg} / \mathrm{kg} \cdot \mathrm{d}$, from which the acceptable HD level in the concrete is calculated as $210 \mathrm{mg} / \mathrm{kg}$.

The occupational RfD for GA is $5.71 \times 10^{-5} \mathrm{mg} / \mathrm{kg} \cdot \mathrm{d}$, from which the acceptable level in the concrete is calculated as $14 \mathrm{mg} / \mathrm{kg}$. 
The occupational RfD for cyanide ion is $1.43 \mathrm{mg} / \mathrm{kg} \cdot \mathrm{d}$, from which the acceptable level of cyanide in the concrete is calculated as $350,000 \mathrm{mg} / \mathrm{kg}$.

The occupational RfD for sulfide (as hydrogen sulfide) is $4.0 \mathrm{mg} / \mathrm{kg} \cdot \mathrm{d}$. If sulfide behaves similarly to nonionic organic materials in being able to penetrate the skin, the acceptable level in the concrete is calculated as $976,000 \mathrm{mg} / \mathrm{kg}$. 


\section{Public Health Risk Assessment}

This assessment assumes that impact rams in open air are used to remove the floor (Scenario II). Exposures to the off-site general public rather than to on-site workers are addressed.

\subsection{Inhalation of Respirable Dust and, Where Applicable, Vapor}

Off-site concentrations for open-air operations would, of course, be higher than those for operations conducted in a sealed building (Scenario I). They should not, however, be dangerously high. Particle generation is described in Section 5.1.2.1.

\subsubsection{Assumptions Regarding Inhalation of Suspended Particles}

These assumptions are similar to those presented in Section 5.1.1.2, except that in this case concern is for the general public. Members of the public are usually only passers-by, and the wind often does not blow toward them; moreover, dust gradually disperses both laterally and vertically and also settles or is intercepted by vertical surfaces. For these reasons, it may be conservatively assumed that the general population would be exposed to no more than one-tenth of the dust level calculated for workers. Hence (see Section 5.1.2.4), the exposure resulting from $1 \mathrm{mg} / \mathrm{kg}$ of contaminant in concrete through dust inhalation would be $8.40 \times 10^{-11} \mathrm{mg} / \mathrm{kg} \cdot \mathrm{d}$. More detailed estimates and their dependence on meteorological conditions will be provided at a later date, if needed.

\subsubsection{Permissible Toxicant Levels in the Concrete Floors}

For WP (see Section 3.4), the general population subchronic RfD is $1.5 \times 10^{-4} \mathrm{mg} / \mathrm{kg} \cdot \mathrm{d}$, and any concentration in the concrete should be acceptable.

For HD, the general population subchronic RfD is $3.57 \times 10^{-5} \mathrm{mg} / \mathrm{kg} \cdot \mathrm{d}$, and the calculated acceptable concentration in concrete is $425,000 \mathrm{mg} / \mathrm{kg}$.

The general population subchronic RfD for GA was calculated as $1.07 \times 10^{-6} \mathrm{mg} / \mathrm{kg} \cdot \mathrm{d}$; hence, an acceptable level in the concrete should be $12,700 \mathrm{mg} / \mathrm{kg}$.

The general population subchronic RfD for cyanide is $0.02 \mathrm{mg} / \mathrm{kg} \cdot \mathrm{d}$, and any level of cyanide in the concrete is acceptable for the general population if only the dust inhalation route is considered.

The general population subchronic RfD for sulfide is $0.0032 \mathrm{mg} / \mathrm{kg} \cdot \mathrm{d}$, and any level of sulfide in the concrete is acceptable for the general population if only the dust inhalation route is considered. 


\subsubsection{A Special Concern Regarding Cyanide and Sulfide}

As in Section 5.1.1.5, it should be considered that aqueous solutions of cyanide and sulfide salts resulting from the extraction of these salts from concrete are capable of emitting vapors of hydrogen cyanide or hydrogen sulfide. Here, the same principles are used, except that the box volume is that of Section 5.1.2.2 (i.e., $16.8 \times 23.4 \times 2=786 \mathrm{~m}^{3}$ ), as is the number of air exchanges $(51,000)$. Moreover, a factor of 0.1 is applied to account for the fact that members of the public are usually only passers-by and that the wind may be blowing away from them. Hence, for the pulverized concrete generated by the diamond-tipped saw:

$$
\begin{aligned}
c_{v}= & \left(42 \mathrm{ft}^{3} \times 85 \mathrm{lb} / \mathrm{ft}^{3} \times 454,000 \mathrm{mg} / \mathrm{lb} \times 10^{-6} \mathrm{~kg} / \mathrm{kg} \times 0.1\right) \\
& +\left(786 \mathrm{~m}^{3} \times 51,000 \text { air changes }\right) \\
= & 4.04 \times 10^{-6} \mathrm{mg} / \mathrm{m}^{3}
\end{aligned}
$$

An estimate of the vapor concentrations that might be generated with impact rams may also be derived. Here, the estimate of vapor emission, $c_{\mathrm{v}}$, from concrete dust containing $1 \mathrm{mg} / \mathrm{kg}$ of a contaminant becomes:

$$
\begin{aligned}
c_{v}= & 0.01 \times 179 \text { tons } \times 907.2 \mathrm{~kg} / \mathrm{ton} \times 1 \mathrm{mg} / \mathrm{kg} \times 0.1 \\
& +\left(786 \mathrm{~m}^{3} \times 51,000 \text { air changes }\right) \\
= & 4.05 \times 10^{-6} \mathrm{mg} / \mathrm{m}^{3}
\end{aligned}
$$

This number is virtually the same as that derived in the diamond-tipped saw estimate; both lead to general population subchronic reference doses of $14,000 \mathrm{mg} / \mathrm{kg}$ for cyanide and $2,200 \mathrm{mg} / \mathrm{kg}$ for sulfide, regardless of the concentration of dust in the air.

\subsection{Ingestion of Particulates}

\subsubsection{Assumptions Regarding Ingestion of Concrete Particles}

In Section 5.1.2.1, a total emission of $118,000 \mathrm{mg}$ of particulates was estimated. It will be assumed that $60 \%$ of this material is deposited on the ground in an area roughly $120 \mathrm{ft}$ wide $\times 1,000 \mathrm{ft}$ long, that is, within about $0.2 \mathrm{mi}$ leeward of Building E5032; this area is approximately $11,000 \mathrm{~m}^{2}$. Thus, the average fallout is $6.4 \mathrm{mg} / \mathrm{m}^{2}$. If this fallout mixes with the top $0.1 \mathrm{~mm}$ of soil with a bulk density of $1.3 \mathrm{mg} / \mathrm{cm}^{3}$, the concentration of contaminated dust in that very thin surface layer is $49 \mathrm{mg} / \mathrm{kg}$. The transient public is assumed to ingest half as much soil from the area as a workman at the site, nameiy $25 \mathrm{mg}(0.000025 \mathrm{~kg})$ per day. 


\subsubsection{Conclusions as to Toxicant Exposure by Ingestion}

Total public consumption of the contaminated demolition-site dust is $49 \times 2.5 \times 10^{-5}=$ $0.00123 \mathrm{mg} / \mathrm{d}$. At a toxicant concentration of $1 \mathrm{mg} / \mathrm{kg}$, the ingestion rate of toxicant is $1.23 \times 10^{-9} \mathrm{mg} / \mathrm{d}$ or, for a $70-\mathrm{kg}$ person, $1.76 \times 10^{-11} \mathrm{mg} / \mathrm{kg} \cdot \mathrm{d}$.

\subsubsection{Permissible Toxicant Levels in the Concrete Floors}

For WP (see Section 3.4), the general population RfD is $1.5 \times 10^{-4} \mathrm{mg} / \mathrm{kg} \cdot \mathrm{d}$, and any WP level in the concrete would be considered acceptable.

For $\mathrm{HD}$, the general population $\mathrm{RfD}$ is $3.57 \times 10^{-5} \mathrm{mg} / \mathrm{kg} \cdot \mathrm{d}$, and any $\mathrm{HD}$ level in the concrete would be acceptable.

The general population RfD for GA is $1.07 \times 10^{-6} \mathrm{mg} / \mathrm{kg} \cdot \mathrm{d}$, and the calculated acceptable concentration level in concrete is $60,000 \mathrm{mg} / \mathrm{kg}$.

The general population subchronic oral RfD for cyanide ion is $0.02 \mathrm{mg} / \mathrm{kg} \cdot \mathrm{d}$, and any level of cyanide in the concrete would be acceptable.

The general population subchronic oral RfD for sulfide is $0.03 \mathrm{mg} / \mathrm{kg} \cdot \mathrm{d}$, and any level of sulfide in the concrete would be acceptable.

\subsection{Dermal Exposure}

\subsubsection{Assumptions Regarding Contact of Skin with Soil Containing Concrete Dust}

In Section 5.1.2.1, a total emission of $118,000 \mathrm{mg}$ of particulates was estimated. It will be assumed that $60 \%$ of this material is deposited on the ground in an area roughly $120 \mathrm{ft}$ wide $\times 1,000 \mathrm{ft}$ long, that is, within about $0.2 \mathrm{mi}$ leeward of Building E5032; this area is approximately $11,000 \mathrm{~m}^{2}$. Thus, the average fallout is $6.4 \mathrm{mg} / \mathrm{m}^{2}$. If this fallout mixes with the top $0.1 \mathrm{~mm}$ of soil with a bulk density of $1.3 \mathrm{mg} / \mathrm{cm}^{3}$, the concentration of contaminated dust in that very thin surface layer is $49 \mathrm{mg} / \mathrm{kg}$. It is assumed that a transient person might have his or her head, arms, and legs uncovered. The total area for these body parts is approximately $1.0 \mathrm{~m}^{2}$ (EPA 1989a). An assumed soil loading on skin of $1.45 \mathrm{mg} / \mathrm{cm}^{2}$ (EPA 1988) thus implies a soil load of $14,500 \mathrm{mg}$ per person per day. Although certain types of soil-borne compounds of very low vapor pressure in contact with skin are absorbed at the rate of about $1 \%$ in $12 \mathrm{~h}$ (Yang et al. 1989), it will be assumed here that for the compounds of interest the total absorption efficiency is $10 \%$. 


\subsubsection{Conclusions as to Toxicant Exposure}

The toxicant absorption rate for concrete dust contaminated with $1 \mathrm{mg} / \mathrm{kg}$ of a toxicant is calculated as $1 \times 0.1 \times 14,500 \times 49 \times 10^{-12}+70=1.0 \times 10^{-9} \mathrm{mg} / \mathrm{kg} \cdot \mathrm{d}$ for a person weighing $70 \mathrm{~kg}$.

\subsubsection{Permissible Toxicant Levels in the Concrete Floors}

For WP, the general population $\mathrm{RfD}$ is $1.5 \times 10^{-4} \mathrm{mg} / \mathrm{kg} \cdot \mathrm{d}$, from which the acceptable WP level in the concrete is calculated as $150,000 \mathrm{mg} / \mathrm{kg}$.

For $\mathrm{HD}$, the general population $\mathrm{RfD}$ is $3.57 \times 10^{-5} \mathrm{mg} / \mathrm{kg} \cdot \mathrm{d}$, fiom which the acceptable level in the concrete is calculated as $35,000 \mathrm{mg} / \mathrm{kg}$.

The general population RfD for GA is $1.07 \times 10^{-6} \mathrm{mg} / \mathrm{kg} \cdot \mathrm{d}$, from which the acceptable level in the concrete is calculated as $1,100 \mathrm{mg} / \mathrm{kg}$.

The general population subchronic RfD for cyanide is $0.02 \mathrm{mg} / \mathrm{kg} \cdot \mathrm{d}$, and any level of cyanide in the concrete would be acceptable.

For the present exercise, it will be assumed that sulfide penetrates the skin in a manner similar to that of neutral organic compounds. The general population subchronic RfD for sulfide is $0.03 \mathrm{mg} / \mathrm{kg} \cdot \mathrm{d}$, and any level of sulfide in the concrete would be acceptable.

\subsection{Risks to Public Health and the Environment from Rainwater Runoff}

\subsubsection{Reasonable Assumptions as to Transport of Toxicants by Runoff}

Construction and demolition contractors are obliged to reduce soil erosion and the level of suspended matter in rainwater runoff to the extent possible. Bundles of straw are often used to control erosion. It is reasonable to require that rubble piles be covered while waiting to be removed from the demolition site and that rubble be removed at the end of each workday. Thus, toxicants present in the concrete would migrate off-site only after being leached from the portion of concrete that had been pulverized and exposed for a time to the elements. The leaching would not be very efficient and would occur only during sufficiently heavy rainfalls. For the present exercise, the following is assumed:

1. One or more 1 -in. $(2.5-\mathrm{cm})$ rainstorms occur during the demolition period;

2. Contaminated area coverage is $4,217 \mathrm{ft}^{2}\left(392 \mathrm{~m}^{2}\right)$;

3. The mass of pulverized concrete is $1 \%$ of the total mass (179 tons, as estimated previously) of concrete floor, that is, $1,620 \mathrm{~kg}$ (based on the estimate hy Murthy and Chatterjee [1976] that "about $1 \%$ of the material demolished could 
become particulate emissions unless suitable measures to prevent dust formation during wrecking were instituted");

4. Efficiency of extraction by the rainwater of toxicants from the pulverized concrete (by weight) is less than or equal to $1 \%$, especially if the rubble has been rapidly removed or properly covered;

5. Runoff in a layer no more than $1 \mathrm{~cm}$ thick moves at about $1 \mathrm{ft} / \mathrm{s}(0.3 \mathrm{~m} / \mathrm{s}$ or $18 \mathrm{~m} / \mathrm{min}$ ) over the entire course of about $2,000 \mathrm{~m}$ before encountering a target receptor, and

6. In the course of its travel, the runoff from the contaminated site is diluted 100 -fold before reaching the target receptor.

\subsubsection{Toxicant Exposure from Rainwater Runoff}

For a concentration of toxicant in the concrete of $1 \mathrm{mg} / \mathrm{kg}$, the concentration in water to which the receptor would be exposed, in the absence of degradative reactions (e.g., hydrolysis), would be calculated as follows:

$$
\begin{aligned}
c_{w} & =\cdot(1,620 \mathrm{~kg} \times 1 \mathrm{mg} / \mathrm{kg} \times 0.01 \times 0.01) \div\left(392 \mathrm{~m}^{2} \times 0.025 \mathrm{~m} \times 1,000 \mathrm{~L} / \mathrm{m}^{3}\right) \\
& =1.65 \times 10^{-5} \mathrm{mg} / \mathrm{L}
\end{aligned}
$$

However, dilute cyanide and sulfide at substantially neutral $\mathrm{pH}$ would volatilize rapidly under the thin layer of turbulent flow described for rainwater runoff, with almost no residue. At the flow rate assumed, it would take the toxicant solution $2,000 / 18=111 \mathrm{~min}$ to reach the hypothetical target receptor. With 3.5- and 4.5-min half-lives, respectively, WP would have undergone a degradation to $2.9 \times 10^{-10}$ of the originally calculated concentration, namely $5 \times 10^{-15} \mathrm{mg} / \mathrm{L}$, and HD would have undergone a degradation of $3.7 \times 10^{-8}$ of the originally calculated concentration, namely $6 \times 10^{-13}$.

Only in the case of GA would the toxicant have been substantially preserved (ignoring some volatilization); about $85 \%$ would remain, given a half-life at $\mathrm{pH} 7$ of $8.5 \mathrm{~h}$ (Edgewood Arsenal 1974).

\subsubsection{Permissible Toxicant Levels in the Concrete Floors}

As discussed above, four of the compounds of concern would be almost completely lost, even at rather high initial loadings in the concrete. If the drinking water criterion for $\mathrm{GA}$ (Baronian 1988 ), $2.8 \times 10^{-3} \mathrm{mg} / \mathrm{L}$, (in lieu of a criterion for aquatic life) and the $85 \%$ persistence figure are used, the permissible concentration in the concrete comes to about $200 \mathrm{mg} / \mathrm{kg}$ for GA. Any unspecified exposures that might occur would probably affect lower forms of aquatic life rather than humans and would be of short duration (acute or subacute). 


\section{Summary and Discussion}

The calculated single-pathway criterion values derived in Sections 5 and 6 are based on numerous more or less reasonable assumptions that are subject to revision as additicinal information becomes available. In particular, if demolition is to be carried out in a sealed biliding, it will be necessary to scale the estimates in Section 5.1 of exposure by dust inhalation to reflect actual airborne dust concentrations. The criterion values represent average levels below which endangerment of relatively unprotected personnel is extremely unlikely. Thus, minor exceedances of a criterion value at a few sampling points would not necessarily imply that a toxicant would reach a dangerous level in media to which people are directly exposed.

Criteria for the compounds of interest at Building E5032 are shown in Tables 2-5. The composite criterion for a compound is a value derived from the various single-pathway criteria, $\mathrm{C}_{\mathrm{i}}$, for a given medium (here, for concrete floors). Its inverse is the sum of inverses for the singlepathway criteria, namely:

$$
\frac{1}{C}=\sum_{i} \frac{1}{C_{i}}
$$

This equation is derived as follows:

$$
\begin{aligned}
& \mathrm{TAD}=\text { total allowable daily dose }(\mathrm{mg} / \mathrm{d}) \\
& \mathrm{K}_{\mathrm{i}}=\text { combined exposure constant for pathway } \mathrm{i} \text {; } \\
& \mathrm{C}_{\mathrm{i}}=\text { chemical-specific limiting concentration for the toxicant of concern via }
\end{aligned}
$$

TAD is defined as $K_{i} \times C_{i}$; hence, $K_{i}=T A D / C_{i}$ and $\Sigma K_{i}=T A D \Sigma\left(1 / C_{i j}\right)$. However, it is equally true that $\mathrm{TAD}=\mathrm{C} \Sigma \mathrm{K}_{\mathrm{i}}=\mathrm{C} \times \mathrm{TAD} \times \Sigma\left(1 / \mathrm{C}_{\mathrm{i}}\right)$, whence $\mathrm{C} \times \Sigma\left(1 / \mathrm{C}_{\mathrm{i}}\right)=1$ and $\mathrm{C}^{-1}=\Sigma\left(1 / \mathrm{C}_{\mathrm{i}}\right.$ or $\left.\Sigma \mathrm{C}_{\mathrm{i}}^{-1}\right)$.

To permit recommendation of adequate sensitivity for analytical testing, criteria in Table 5 were calculated on the assumption of exposure to dust concentrations of $15 \mathrm{mg} / \mathrm{m}^{3}$ in Scenario I. These calculations were only needed for the inhalation and composite criteria for WP, HD, and GA because the vapor-based criteria for cyanide and sulfide would not change with dust concentration. The level $15 \mathrm{mg} / \mathrm{m}^{3}$ was chosen because it is the level above which protective measures would have to be taken against "particulates not otherwise regulated -- total dust," that is, nuisance dust (DOL 1990). 
TABLE 2 Concrete Floor Occupational Health Criteria, Scenario I (mg/kg)

\begin{tabular}{lrrrc}
\hline Contaminant & Inhalation & - Ingestion & $\begin{array}{r}\text { Dermal } \\
\text { Absorption }\end{array}$ & $\begin{array}{c}\text { Composite } \\
\text { Criterion }\end{array}$ \\
\hline WP & $100,000^{\mathrm{a}}$ & 40,000 & 7,000 & $5,600^{\mathrm{b}}$ \\
HD & $3,000^{\mathrm{a}}$ & 1,200 & 210 & $169^{\mathrm{b}}$ \\
GA & $200^{\mathrm{a}}$ & 80 & 14 & $11.2^{\mathrm{b}}$ \\
Cyanide & 500 & Any level & 350,000 & 500 \\
Sulfide & 1,400 & Any level & Any level & 1,400 \\
\hline
\end{tabular}

aBased on the assumption that the emitted dust concentration is $1 \mathrm{mg} / \mathrm{m}^{3}$. Values for the alternative exposure conditions described for jackhammer operators, at an average dust concentration of

$6.25 \mathrm{mg} / \mathrm{m}^{3}$, are WP, 16,000; HD, 480; and GA, 32 .

bComposite criteria when the dust inhalation contributions are based on the jackhammer operator calculations are WP, 4,350; HD, 130; and GA, 9.6.

TABLE 3 Concrete Floor Occupational Health Criteria, Scenario II (mg/kg)

\begin{tabular}{lcrrr}
\hline Contaminant & Inhalation & Ingestion & $\begin{array}{r}\text { Dermal } \\
\text { Absorption }\end{array}$ & $\begin{array}{r}\text { Composite } \\
\text { Criterion }\end{array}$ \\
\hline WP & Any levela & 40,000 & 7,000 & $6,000^{\mathrm{b}}$ \\
HD & Any levela & 1,200 & 210 & $179^{\mathrm{b}}$ \\
GA & $68,000^{\mathrm{a}}$ & 80 & 14 & $12^{\mathrm{b}}$ \\
Cyanide & 123,000 & Any level & 350,000 & 91,000 \\
Sulfide & 346,000 & Any level & Any level & 346,000 \\
\hline
\end{tabular}

avalues for the alternative exposure conditions described for jackhammer operators, at an average dust concentration of $6.25 \mathrm{mg} / \mathrm{m}^{3}$, are WP, 16,000; HD, 480; and GA, 32 .

bComposite criteria when the dust inhalation contributions are based on the jackhammer operator calculations are WP, 4,350; HD, 130; and GA, 9.6 . 
TABLE 4 Concrete Floor Public Health Criteria, Scenario II (mg/kg)

\begin{tabular}{lrrrrr}
\hline Contaminant & Inhalation & Ingestion & $\begin{array}{r}\text { Dermal } \\
\text { Absorption }\end{array}$ & $\begin{array}{r}\text { Raimwater } \\
\text { Runoff }\end{array}$ & $\begin{array}{r}\text { Composite } \\
\text { Criterion }\end{array}$ \\
\hline WP & Any level & Any level & 150,000 & Any level & 150,000 \\
HD & 425,000 & Any level & 35,000 & Any level & 32,000 \\
GA & 12,700 & 60,000 & 1,100 & 200 & 1,000 \\
Cyanide & 14,000 & Any level & Any level & Any level & 14,000 \\
Sulfide & 2,200 & Any level & Any level & Any level & 2,200 \\
\hline
\end{tabular}

aThe rainwater value is not included because the target population is different.

It may tentatively be concluded that the presence in the concrete floors of Building E5032 (the most likely repository of traces of contaminants resulting from past accidental spills) of the five suspect contaminants at the following levels (which would be the preferred maximum analytical sensitivity values) -- and possibly at higher levels -.- would pose no occupational or public health hazards under the assumed conditions for any of the selected scenarios:

WP

$\mathrm{HD}$

GA

Cyanide

Sulfide
TABLE 5 Concrete Floor Occupational Health Criteria for Maximum Allowable Dust Level, Scenario I (mg/kg)

\begin{tabular}{lrr}
\hline Contaminant & Inhalation & $\begin{array}{c}\text { Composite } \\
\text { Criterion }\end{array}$ \\
\hline WPa & 6,700 & 3,200 \\
$\mathrm{HD}^{\mathrm{a}}$ & 200 & 94 \\
$\mathrm{GA}^{\mathrm{a}}$ & 13 & 6 \\
\hline
\end{tabular}

aBased on the assumption that the emitted dust concentration is $15 \mathrm{mg} / \mathrm{m}^{3}$.

It is highly unlikely that transient episodes of extraction of contaminants by rainwater would result in sufficient surface water contamination to harm aquatic biota. However, the foregoing criteria were not intended to apply to levals in vessels, pipes, or sumps. 


\section{References}

Baronian, C. (preparer), 1988, Chemical Stockpile Disposal Program, Final Programmatic Environmental Impact Statement, Volume 3, Office of the Program Manager for Chemical Demilitarization, U.S. Army, Aberdeen Proving Ground, Md., Jan.

Berkow, R., 1987, Cryptococcosis (torulosis), in The Merck Manual of Diagnosis and Therapy, 15th Ed., R. Berkow, ed., Merck Sharpe and Dohme Research Laboratories, Rahway, N.J, pp. 141-142.

Bodek, I., et al., 1988, Environmental Inorganic Chemistry: Properties, Processes and Estimation Methods, Pergamon Press, New York.

Borland, M.M., R.L. Yon, and G.M. Grove, 1989, Historical Records Search and Site Survey of Edgewood Area Buildings, Final Report, EAI Corporation, Abingdon, Md., prepared for U.S. Army Chemical Research, Development and Engineering Center, Aberdeen Proving Ground, Md., under Contract DAAA-15-87-D-0021, Task 021, August.

Carpenter, T.J., a.d T.E. Hill, 1988, Methods for Demolition of Building E5625, prepared by Battelle Columbus Division, Columbus, Ohio, for the U.S. Army Chemical Research, Development, and Engineering Center, Aberdeen Proving Ground, Md., under Contract DAAA15-87-D-0)11, Task 6, Nov.

Cowherd, C., Jr., et al., 1984, Rapid Assessment of Exposure to Particulate Emissions from Surface Contamination Sites, Midwest Research Institute, Kansas City, Mo., prepared for the Office of Health and Environmental Assessment, U.S. Environmental Protection Agency, under Contract 68-03-3116, Sept.

Davidson, K.A., P.S. Hovatter, and C.F. Sigmon, 1987, Water Quality Criteria for White Phosphorus, prepared by Oak Ridge National Laboratory for the U.S. Army Medical Research and Development Command, Fort Detrick, Frederick, Md., under Army Project Order No. 84PP4845, Report ORNL-6336, August.

U.S. Department of Labor (DOL), 1986, Occupational Exposure to Asbestos, Tremolite, Anthophyllite, and Actinolite; Final Rules, Occupational Safety and Health Administration, 29 CFR Parts 1910 and 1926, Federal Register Vol. 51, No. 119, June 20.

DOL, 1990, Occupational Safety and Health Standards, Toxic and Hazardous Substances, 29 CFR Ch. XVII, Part 1910.1000, Subpart Z, August 1.

Edgewood Arsenal, 1974, Chemical Agent Data Sheets, Volume I, Department of the Army, Aberdeen Proving Ground, Md., Edgewood Arsenal Special Report EO-SR-740001, Dec.

Emmons, C.W., 1955, Saprophytic sources of Cryptococcus neoformans associated with the pigeon (Columba livia), American Journal of Hygiene, 62:227-232. 
U.S. Environmental Protection Agency (EPA), 1988, Superfund Exposure Assessment Manual, Office of Remedial Response, EPA, Report EPA/540/1-88/001, April.

EPA, 1989a, Exposure Factors Handbook, Office of Health and Environmental Assessment, EPA, Report EPA/600/8-89/043, July.

EPA, 1989b, Risk Assessment Guidance for Superfund, Vol. I: Part A, Human Health Evaluation Manual, Interim Final, Office of Emergency and Remedial Response, EPA, Report EPA/540/1-89/002, Dec.

EPA, 1991, Health Effects Assessment Summary Tables (FY 1991 Annual), Office of Emergency and Remedial Response, EPA, Report OERR 9200.6-303(91-1).

Ethyl Corporation, 1990, Material Safety Data Sheet for TEA (Triethylaluminum), Ethyl Corporation, Materials Group, Baton Rouge, Li., May 10.

Ethyl Corporation, undated, Handling Procedures for Aluminum Alkyl Compounds and Other Organometallics, Ethyl Corporation, Baton Rouge, La.

Grelinger, M.A., et al., 1988, Gap Filling PM 10 Emission Factors for Selected Open Dust Sources, Midwest Research Institute, Kansas City, Mo., prepared for the EPA Office of Air Quality Planning and Standards, Research Triangle Park, N.C., under Contract 68-02-3891, EPA-450/4-88-003 (PB88-196225), Feb.

Jernigan, J.D., R. Bass, and D.J. Paustenbach, 1991, A Cost-Effective Approach to Assessing Contaminated Soil: Set de Minimis Criteria for Eight Different Exposure Scenarios, in The Hazards of Contaminated Soils, Vol. III, P.T. Kostecki and E.J. Calabrese, eds., Lewis Publishers, Inc., New York, Table 3.

Kaye, S.M., 1980, Thermate and Thermite, in Encyclopedia of Explosives and Related Items, Volume 9, Large Caliber Weapon Systems Laboratory, U.S. Army Armament Research and Development Command, Dover, N.J., Report PATR 2700, p. T-189.

Maryland Department of the Environment, 1990, Control of Asbestos, COMAR 26.11.21, Air Management Administration, Maryland Department of the Environment, Baltimore, Md., July.

McNamara, B.P., et al., 1975, Toxicological Basis for Controlling Levels of Mustard in the Environment, Headquarters, Edgewood Arsenal, Aberdeen Proving Ground, Md., Edgewood Arsenal Special Publication EB-SP-74030, June.

Murthy, K.S., and S. Chatterjee, 1976, Development of Predictive Criteria for Demolition and Construction Solid Waste Management, Battelle Columbus Laboratories, Columbus, Ohio, prepared for the U.S. Army Construction Engineering Research Laboratory, Champaign, Ill., under Contract DACA 88-75-C-0015, AD-A033 646, Oct. 
Nemeth, G., 1989, RCRA Facility Assessment Report, Edgewood Area, Aberdeen Proving Ground, Maryland, Abendeen Proving Ground, Test and Evaluation Command, Aberdeen, Md.

Ottinger, R.J., et al., 1973, Recommended Methods of Reduction, Neutralization, Recovery or Disposal of Hazardous Waste, Vol. III: Propellants, Explosives, Chemical Warfare, U.S. Environmental Protection Agency, Report EPA-670/2-73-053-g.

Rosenblatt, D.H., et al., 19:'5, Problem Definition Studies on Potential Environmental Pollutants, II: Physical, Chemical, Toxicological, and Biological Properties of 16 Substances, Appendix A: Mustard Gas/Thiodiglycol, U.S. Army Medical Bioengineering Research and Development Laboratory, Fort Detrick, Frederick, Miu., Technical Report 7509, Dec.

Scharf, A., 1967, Preliminary Report on Reduction of Airborne Dust Produced by Pneumatic Jackhammers, American Industrial Hygiene Assosiation Journal, 28:479-481; 1969, Control of Airborne Dust Produced hy Pneumatic Jackpicks: Report Number II, American Industrial Hygiene Association Journal, 30:519-522.

Small, M.J., 1983, Soil Detection Limits for Potential Chemical Warfare-Related Contaminants at Fort McClellan, Alabama, U.S. Army Medical Bioengineering Research and Development Laboratory, Fort Detrick, Frederick, Md., Technical Report 8208, May.

Small, M.J., 1984, Compounds Formed from the Chernical Decontamination of HD, GB, and VX and their Environmental Fate, U.S. Army Medical Bioengineering Research and Development Laboratory, Fort Detrick, Frederick, Md., Technical Report 8304, June.

Spanggord, R.J., et al., 1985, Environmental Fate of White Phosphorus/Felt and Red Phosphorus/Butyl Rubber Military Screening Smokes, prepared by SRI International, Menlo Park, Calif., for the U.S. Army Medical Research and Development Command, Fort Detrick, Frederick, Md., under Contract DAMD 17-82-C-2320, SRI Project PYU-4937, April.

Spencer, R., 1991, Safety Office, Fort Detrick, Frederick, Md., personal communication, Feb. 5.

Yang, J.J., et al., 1989, Percutaneous Absorption of Benzo(a)pyrene from Soils With and Without Petroleum Crude Contamination, in Petroleum Contaminated Soils, Vol. 2, E.J. Calabrese and P.T. Kostecki, eds., Lewis Publishers, Inc., Chelsea, Mich., pp. 399-407. 

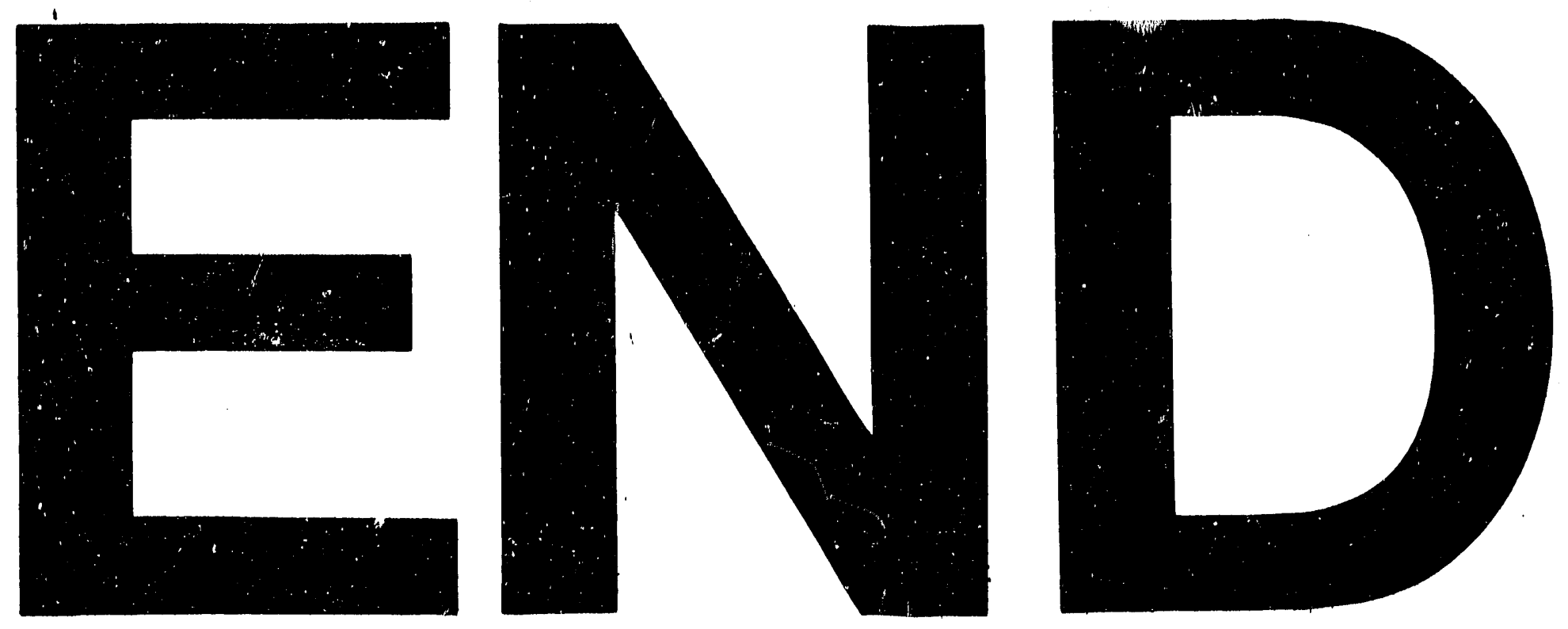

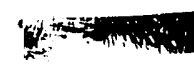
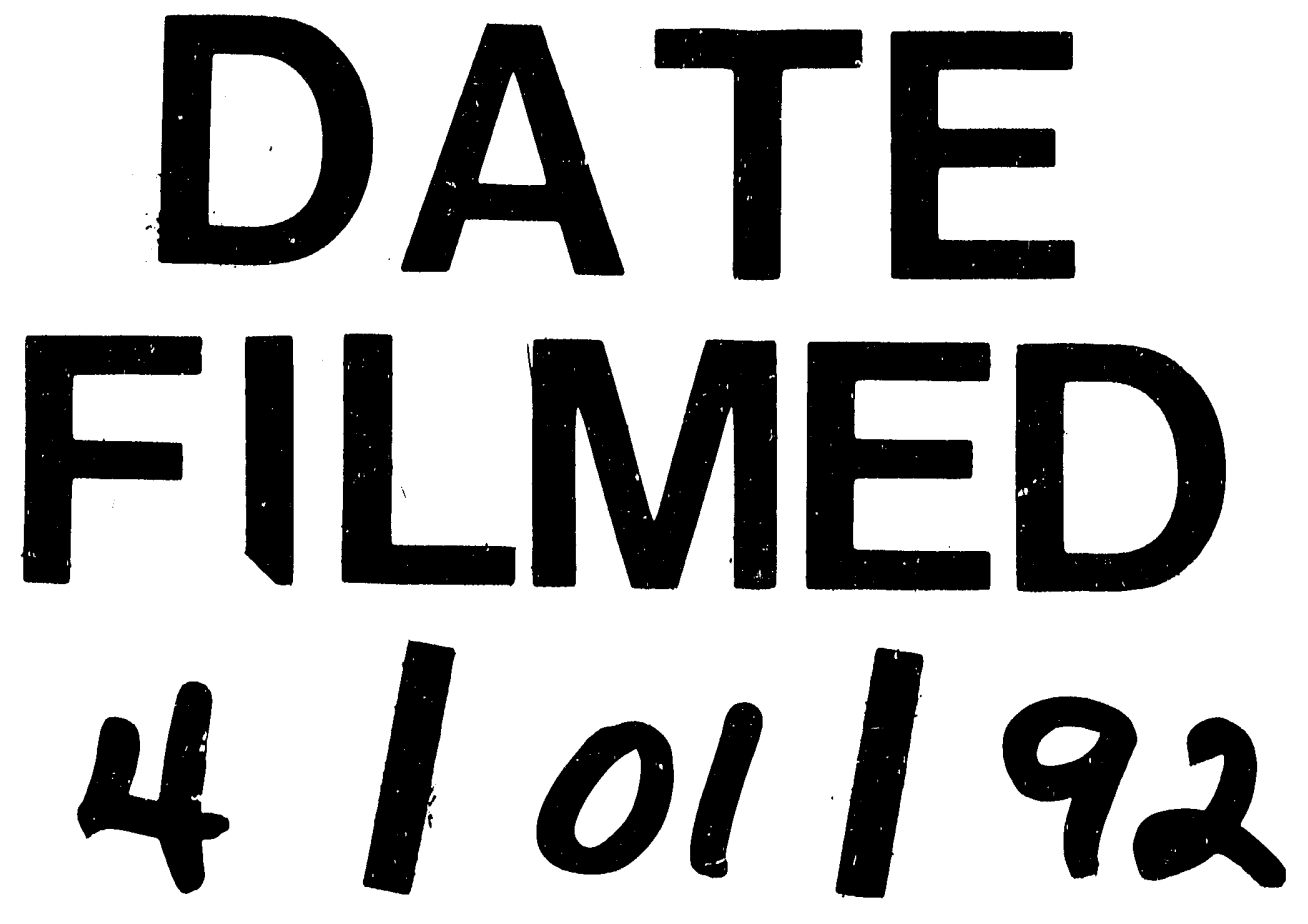

1

$I$ 
